\title{
Personnel
}

Psychology

\section{Work Engagement: A Quantitative Review and Test of its Relations with Task and Contextual Performance}

\begin{tabular}{|r|l|}
\hline Journal: & Personnel Psychology \\
\hline Manuscript ID: & Ppsych-main-10-1057.R3 \\
\hline Manuscript Type: & Main Section Submission \\
\hline Keywords: & Motivation, Job performance/criteria, Stress \\
\hline
\end{tabular}

\section{S) ScholaroNE}

This is the peer reviewed version of the following article: Christian, M. S., Garza, A. S., \& Slaughter, J. E. (2011). Work engagement: A quantitative review and test of its relations with task and contextual performance. Personnel Psychology, 64: 89-136. doi:10.1111/j.1744-6570.2010.01203.x, which has been published in final form at https://doi.org/10.1111/j.1744-6570.2010.01203.x

This article may be used for non-commercial purposes in accordance with Wiley Terms and Conditions for Use of Self-Archived Versions, as can be found on https://authorservices.wiley.com/ author-resources/Journal-Authors/licensing/self-archiving.html 
Running Head: WORK ENGAGEMENT

\author{
Work Engagement: A Quantitative Review and Test of \\ its Relations with Task and Contextual Performance
}

\author{
Michael S. Christian \\ Kenan-Flagler Business School \\ University of North Carolina \\ Adela S. Garza \\ Eli Broad College of Management \\ Michigan State University \\ Jerel E. Slaughter \\ Eller College of Management \\ University of Arizona
}

Author's note. A previous version of this article was presented at the 2007 meeting of the Academy of Management. We would like to acknowledge Jessica Siegel and Edgar Kausel for their helpful comments on the manuscript. 


\begin{abstract}
Many researchers have concerns about work engagement's distinction from other constructs and its theoretical merit. The goals of the current study were to identify an agreed-upon definition of engagement, to investigate its uniqueness, and to clarify its nomological network of constructs. Using a conceptual framework based on Macey and Schneider (2008), we found that engagement exhibits discriminant validity from, and criterion related validity over, job attitudes. We also found that engagement is related to several key antecedents and consequences. Finally, we used meta-analytic path modeling to test the role of engagement as a mediator of the relation between distal antecedents and job performance, finding support for our conceptual framework. In sum, our results suggest that work engagement is a useful construct that deserves further attention.
\end{abstract}


In recent years, work engagement has become a well-known variable to both scientists and practitioners. An emerging body of research is beginning to converge around a common conceptualization of work engagement as connoting high levels of personal investment in the work tasks performed on a job (e.g., Kahn, 1990; Macey \& Schneider, 2008; May, Gilson, \& Harter, 2004; Schaufeli, Salanova, González-Romá, \& Bakker, 2002; Rich, LePine, \& Crawford, 2010). However, several issues remain unresolved that have important implications for the future of engagement research. Historically engagement research has been plagued by inconsistent construct definitions and operationalizations (Macey \& Schneider, 2008). As a result, there is confusion as to whether engagement is conceptually and empirically different from other constructs (e.g., Dalal, Brummel, Wee, \& Thomas, 2008; Macey \& Schneider, 2008; Newman \& Harrison, 2008). Thus, some researchers are ambivalent about the incremental value of engagement over other constructs as a predictor of behavior (Newman \& Harrison, 2008).

Macey and Schneider (2008) point out that "the relationships among potential antecedents and consequences of engagement...have not been rigorously conceptualized, much less studied" (p. 3-4), resulting in an inadequate understanding of work engagement's nomological network. Moreover, although researchers have argued that engagement, as a motivational variable, should lead to high levels of job performance (e.g., Kahn, 1990; Schaufeli, et al., 2002; Rich et al., 2010), we know little about engagement's uniqueness as a predictor of job performance. Thus, the overarching intent of the current research is to resolve these deficiencies by organizing and integrating the available evidence in the literature. Specifically, our goals were to (a) examine the literature to find areas of commonality among the conceptualizations of engagement in order to arrive at an agreed-upon definition, (b) investigate 
the extent to which engagement is a unique construct, and (c) clarify the nomological network of constructs associated with engagement.

The remainder of this study unfolds as follows. We begin by identifying and describing the commonalities contained in this body of research in order to arrive at an operationalization that exhibits relative consensus. We next situate engagement in a conceptual framework that specifies its associations with antecedents, outcomes, and conceptually similar constructs. Using this framework, we then argue that engagement is a unique concept and develop expectations for its discriminant validity. Next, we draw on our framework to discuss the antecedents and consequences (i.e., job performance) of engagement and develop expectations for their correlations. We then argue that engagement will predict job performance over and above the job attitudes in our framework. Next, we propose a test of our framework, which specifies engagement as a mediating link between its antecedents and consequences. Finally, we use metaanalytic techniques to test our predictions.

\section{Defining Work Engagement}

Although there have been many studies that measure constructs that carry the “engagement" label, operational definitions are not always consistent. In order to define engagement in the current research, we reviewed the literature to find commonalities among the measures of the engagement concept. Because the vast majority of studies that we reviewed drew on Kahn (1990) as a conceptual foundation (e.g., Ashforth \& Humphrey, 1995; May et al., 2004; Rothbard, 2001; Saks, 2006; Schaufeli et al., 2002; Rich et al., 2010), we used his work as our starting point for organizing the literature.

Kahn (1990) proposed that personal engagement represents a state in which employees "bring in" their personal selves during work role performances, investing personal energy and 
experiencing an emotional connection with their work. In this view, work roles represent opportunities for individuals to apply themselves behaviorally, energetically, and expressively, in a holistic and simultaneous fashion (Kahn, 1992; Rich et al., 2010). As such, work engagement is fundamentally a motivational concept that represents the active allocation of personal resources toward the tasks associated with a work role (Kanfer, 1990; Rich et al., 2010).

We found two characteristics of Kahn's (1990) conceptualization of engagement to be noteworthy in establishing an operational definition. First, work engagement should refer to a psychological connection with the performance of work tasks, rather than an attitude toward features of the organization or the job (Maslach et al., 2001). Thus, a measure such as the Gallup Workplace Audit (GWA; Harter, Schmitt, \& Hayes, 2002), does not conform to this conceptualization because it refers to work conditions, not the work task. For example, the GWA refers to a range of job characteristics including resource availability, rewards, feedback, task significance, development opportunities, and clarity of expectations (Harter et al., 2002). As shown in Table 1, we identified several measures of work engagement that refer to individuals' experiences during the performance of their work tasks. For example, the Utrecht Work Engagement Scale (UWES) references the experience of working; the Demerouti, Bakker, Vardakou, and Kantas (2003) scale ${ }^{1}$ refers to work tasks; and the May et al. (2004) measure refers to harnessing of employees' selves to their work roles.

Second, work engagement concerns the self-investment of personal resources in work. That is, engagement represents a commonality among physical, emotional, and cognitive energies that individuals bring to their work role (Rich et al., 2010). In this sense, work engagement is more than just the investment of a single aspect of the self; it represents the investment of multiple dimensions so that the experience is simultaneous and holistic (Kahn, 
1992; Rich et al., 2010). Thus, individuals who are engaged are those who experience a connection with their work on multiple levels. We found many measures that refer to the investment of multiple personal resources (see Table 1), either conceptualized as distinct dimensions (e.g., Schaufeli et al., 2002), or as a composite measure representing investment of the entire self (e.g., Saks, 2006). Some researchers report results for each dimension separately (e.g., Schaufeli \& Bakker, 2004) while others report a single factor (e.g., Sonnentag, 2003). However, given that every study that we reviewed that reported dimension-level correlations showed strong correlations among the factors ${ }^{2}$, we conceptualized engagement as a higher-order construct (see LePine, Erez, \& Johnson, 2002). Thus, several measures conceptualizing a single dimension (e.g., cognitive absorption or flow; Bakker, 2005, Rothbard, 2001) did not fit our definition.

Another important factor in defining engagement is its conceptualization as a "state" versus as a "trait." Most of the research conceptualizes engagement as a relatively stable individual difference variable that varies between-persons (e.g., Schaufeli et al., 2002; Schaufeli $\&$ Salanova, 2007). However, recent research has indicated that engagement is subject to moderate day-level fluctuations around an average level (Sonnentag, 2003). This is consistent with Kahn (1990), who postulated that work engagement ebbs and flows-a condition that may vary both between and within individuals. Hence, a debate has emerged as to whether engagement is best thought of as a relatively stable trait, a temporally dynamic state, or both (Dalal et al., 2008). What is clear though, is that engagement varies both between- and withinpersons, which is a common characteristic of many constructs in organizational behavior such as affect (Thoresen, Kaplan, Barsky, Warren, \& de Chemont, 2003) and job satisfaction (Ilies \& Judge, 2002). Thus, we agree with Dalal et al.'s (2008) position, which is that, "what Macey and 
Schneider call state engagement is probably better referred to simply as engagement, with the recognition that engagement is likely to contain both trait-like and state-like components..." (p. 54-55). Therefore, we refer to engagement as a state of mind that is relatively enduring, but may fluctuate over time (Schaufeli et al., 2002). However, because between-person and within-person methods contain different sources of variation, we examined study design as a moderator of engagement's relations with antecedents and consequences.

Thus, based on our review, we defined work engagement as a relatively enduring state of mind referring to the simultaneous investment of personal energies in the experience or performance of work. Next, we turn to a discussion of the nomological network of work engagement.

\section{Conceptual Framework}

In order to develop a model delineating work engagement's relationship with conceptually similar constructs, its antecedents, and consequences, we utilized a modified version of the framework (Figure 1) put forth by Macey and Schneider (2008). This framework was useful for two reasons. First, it offered a clear description of engagement's nomological network. We utilized the portion of the framework specifying engagement's conceptual overlap with job attitudes to organize our discussion of discriminant validity, which we turn to in the following section. Second, we chose this framework because, although not a theory in itself, it specifies engagement's position as a mediating variable situated among its antecedents and outcomes. Specifically, the framework is grounded in the idea that distal antecedents such as job characteristics, leadership, and personality influence proximal motivational factors in order to affect job performance (e.g., Barrick, Mount, \& Strauss, 1993; Hackman \& Oldham, 1980; Kanfer, 1990, 1992; Piccolo \& Colquitt, 2006). This idea is a key tenet of Kahn's (1990) theory 
of engagement, which was based in part on Hackman and Oldham's (1980) notion of critical psychological states. Kahn (1990) proposed that individual and organizational factors influence the psychological experience of work, and that this experience drives work behavior. Following from this, Macey and Schneider (2008) identified several distal antecedents that influence the extent to which an individual should experience a desire to self-invest their personal energies into performing their work at a high level. Thus, by drawing on research from job characteristics theory (Hackman \& Oldham, 1980), charismatic leadership (e.g., Bass \& Avolio, 1990), and personality, Macey and Schneider (2008) make the case that (a) job characteristics, (b) leadership, and (c) personality traits should all be directly related to work engagement, and thus indirectly related to performance.

\section{Discriminant Validity with Job Attitudes}

A particularly important question to researchers and practioners is whether work engagement is simply a re-packaging of similar constructs (Macey \& Schneider, 2008). The idea that engagement is measured with bits and pieces of other constructs is otherwise known as the “Jangle Fallacy" (Kelley, 1927), or putting “old wine in a new barrel” (Macey \& Schneider, 2008). Although engagement measures may share some item content with measures of other constructs (Newman \& Harrison, 2008), it is likely that these items are combined in such a way as to create a unique concept (Macey \& Schneider, 2008). Despite this conjecture, little empirical evidence exists to affirm that engagement is distinct from other similar constructs. Thus, evidence of discriminant validity-correlations that are not too high between constructs that are purported to be different (Campbell \& Fiske, 1959)-must be established in order to verify that engagement is unique from other constructs. As noted by Harter and Schmidt (2008), "a key question is whether the newer constructs of engagement have discriminant validity relative to the 
older constructs of job satisfaction and organizational commitment...” (p. 36). If the correlations between engagement and job attitudes are considerably less than 1.00, they can be considered empirically distinct (Anderson \& Gerbing, 1988; Harter \& Schmidt, 2008). We next discuss how engagement is distinguishable from job satisfaction, organizational commitment, and job involvement.

Job satisfaction. Job satisfaction is an attitude often defined as a "positive (or negative) evaluative judgment one makes about one's job or job situation" (Weiss, 2002; p. 175). Job satisfaction and engagement have fundamental differences, in that engagement connotes activation, as opposed to satisfaction, which is more similar to satiation (Erickson, 2005; Macey $\&$ Schneider, 2008). Further, job satisfaction is an evaluative description of job conditions or characteristics (e.g., "I like my pay"), which is a feature of a job attitude (Brief \& Weiss, 2002; Eagly \& Chaiken, 1993), whereas work engagement is a description of an individual's experiences resulting from the work (e.g., "I feel vigorous when working").

Organizational commitment. Affective organizational commitment (AC) is characterized by an emotional attachment to one's organization that results from shared values and interests (Mowday, 1998). As we have argued, the most common conceptualization of engagement differs from AC in two ways. First, AC references an affective attachment to the values of the organization as a whole (Brooke, Russell, \& Price, 1988), whereas engagement represents perceptions that are based on the work itself (Maslach et al., 2001). Second, engagement is a broader construct in that it involves a holistic investment of the self, in terms of cognitive, emotional, and physical energies. In the sense that AC represents an emotional state of attachment, Macey and Schneider (2008) suggested that commitment might be a facet of engagement, but not sufficient for engagement. 
Job involvement. Kanungo (1982) defined job involvement as a "cognitive or belief state of psychological identification" (p. 342). Job involvement refers to the cognitive belief that a job satisfies one's needs, and represents the degree to which an individual identifies strongly with that job both at work and outside of work (Brown, 1996). As such, job involvement reflects the centrality of performance to an individual because it represents the degree to which job performance affects an employee's self-esteem (Lodahl \& Kejner, 1965). Engagement differs from job involvement in two ways. First, job involvement is a cognitive construct (Kanungo, 1982), and as a result, might be considered a facet of engagement rather than equated with engagement (Macey \& Schneider, 2008; Salanova, Agut, \& Peiro, 2005). Second, job involvement refers to the degree to which the job situation, broadly defined, is central to an individual's identity (Kanungo, 1982). Thus it does not refer to work tasks specifically, but rather to aspects of the job, including how much the job can satisfy an individual's needs.

Thus, we expected that engagement's relation with job attitudes would be moderate and positive, indicating discriminant validity. If engagement is a unique concept, relationships among its nomological network of antecedents and consequences are important to verify in order to establish its theoretical relevance. Thus, we next turn to a discussion of the antecedents and consequences of engagement specified by our framework.

\section{Antecedents}

Job characteristics. Job characteristics theory (Hackman \& Oldham, 1976) suggests that features of the work environment facilitate motivation, which is empirically documented (Fried \& Ferris, 1987). Both Kahn (1990) and Macey and Schneider (2008) argue that some aspects of work are intrinsically motivating, and will thus affect the extent to which an individual is willing to self-invest their personal energy in their tasks. Recently, the job characteristics model has been 
expanded to include three distinct categories of motivating factors associated with work design (Humphrey, Nahrgang, \& Morgeson, 2007). These include motivational, social, and work context characteristics ${ }^{3}$.

Motivational characteristics likely associated with engagement include autonomy (freedom in carrying out one's work), task variety (performing different tasks at a job), task significance (how much a job impacts others' lives), feedback (the extent to which a job provides performance information), problem solving (the extent to which a job requires innovative solutions or new ideas), and job complexity (the extent to which a job is multifaceted and difficult to perform). These characteristics motivate workers by engendering experiences of meaningfulness, responsibility, and knowledge of results (Hackman \& Oldham, 1976). Because employees who have resources that facilitate their job tasks are more apt to invest energy and personal resources in their work roles (Bakker, Emmerik, \& Euwema, 2006; Salanova et al., 2005), we expected that work engagement would be positively related to autonomy, task variety, task significance, feedback, problem solving, and job complexity.

Social support (the extent to which a job provides opportunities for assistance and advice from supervisors or coworkers) is a social characteristic likely associated with engagement. Kahn (1990) reported that engagement was increased when the work included rewarding interactions with co-workers. Social characteristics motivate by creating meaningfulness (Gersick, Bartunek, \& Dutton, 2000; Kahn, 1990), resilience, and security (Ryan \& Deci, 2001). Thus, we expected that engagement would be positively related to social support.

Physical demands (the amount of physical effort necessary for a job) and work conditions (health hazards, temperature, and noise) are contextual work demands likely associated with engagement. Recent work by Humphrey and colleagues (2007) suggests that work context 
demands should be conceptually integrated into the job characteristics model developed by Hackman and Oldham (1976) because they represent a class of job characteristics that focus on contextual features of one's work and are thus non-redundant with motivational characteristics or with social characteristics, which focus on individual job components and interactional components respectively. Further, Kahn (1990) suggested that because physical demands and work conditions lead workers to perform tasks as if guided by external scripts, rather than selfinvest in their work, they are likely to be negatively associated with engagement. As physical demands and stressful work conditions increase, workers will become physically uncomfortable (Campion, 1988), leading to more negative experiences while at work (Humphrey et al., 2007). Thus, we expected that engagement would be negatively related to physical demands and work conditions.

Leadership. Leaders are critical elements of the work context that can influence how workers view their work. In line with the arguments presented by Kahn (1990), Macey and Schneider (2008) argue that when leaders have clear expectations, are fair, and recognize good performance, they will have positive effects on employee engagement by engendering a sense of attachment to the job. Further, when employees have trust in their leaders, they will be more willing to invest themselves in their work because they feel a sense of psychological safety (Kahn, 1990). Specifically, research suggests that transformational leaders are able to bring about feelings of passion and identification with work (Bass \& Avolio, 1990; Macey \& Schneider, 2008). Leaders that display positive affect and charisma tend to produce similar levels of activation and positive affect in their followers (George, 2000). The quality of leader-member relationships, or leader-member exchange (LMX; Graen \& Scandura, 1987), also positively affects follower's positive emotions and attitudes (Engle \& Lord, 1997; Gerstner \& Day, 1997). 
Therefore, we expect engagement to be positively related to transformational leadership and LMX.

Dispositional factors. Kahn (1990) argued that dispositional individual differences are likely to shape people's tendencies towards engagement. As such, dispositional factors are a key set of antecedents in the Macey and Schneider (2008) framework. In particular, personality traits concerned with human agency, or the ability of people to control their thoughts and emotions in order to actively interact with their environments (Bandura, 2001) are likely to lead to engagement (Hirschfeld \& Thomas, 2008). These traits include conscientiousness, positive affect, and proactive personality.

First, we expected that conscientiousness would be positively related to engagement, because conscientious individuals have a strong sense of responsibility and are thus more likely to involve themselves in their job tasks (e.g., Furnham, Petrides, Jackson, \& Cotter, 2002). Also, we expected that trait positive affect (PA), known as extraversion in some personality theories (Watson, Clark, \& Tellegen, 1988) would be positively related to engagement. Individuals high in PA are predisposed to experiencing activation, alertness, and enthusiasm (Macey \& Schneider, 2008; Watson \& Clark, 1997). In support, PA has been linked directly to motivation (Judge \& Ilies, 2002). Finally, we expected that proactive personality would positively relate to engagement. Proactive individuals demonstrate initiative and perseverance (Bateman \& Crant, 1993; Crant, 1995). Proactive personality is likely related to engagement because individuals who are involved in their work environment are also likely to immerse themselves in their work.

\section{Consequences}

Engagement, as we have conceptualized it, focuses on the actual work performed at a job, and represents the willingness to dedicate physical, cognitive, and emotional resources to this 
work. As Kahn (1990) suggested, an engaged individual is one who approaches the tasks associated with a job with a sense of self-investment, energy, and passion, which should translate into higher levels of in-role and extra-role performance.

Task performance. In-role performance, which we refer to as task performance, is how well individuals perform the duties required by the job (Borman \& Motowidlo, 1997). As a motivational concept, engagement should relate to the persistence and intensity with which individuals pursue their in-role performance (Ashforth \& Humphrey, 1995; Burke, 2008;Kanfer, 1990; Rich et al., 2010). Engaged employees will be more vigilant and more focused on their work tasks, and thus, engagement should be positively related to task performance.

Contextual performance. When individuals invest energy into their work roles, they should have higher contextual performance, which relates to an individuals' propensity to behave in ways that facilitate the social and psychological context of an organization (Borman \& Motowidlo, 1993). Engagement is thought to be an indicator of an employee's willingness to expend discretionary effort to help the employer (Erickson, 2005). Kahn (1990) suggested that individuals who invest their personal selves into their work role are likely to carry a broader conception of that role, and are more likely to step outside of the formal boundaries of their job to facilitate the organization at large and the people within (cf. Rich et al., 2010). Thus, we expected that work engagement would be positively related to contextual performance.

Incremental validity for task and contextual performance. If engagement exhibits relations with job performance, it is important to determine whether it explains variance over the job attitudes discussed earlier that share its conceptual space. We expected that engagement would explain incremental variance in job performance over and above job satisfaction, organizational commitment, and job involvement. As we have argued, although engagement 
shares some conceptual space with each of these constructs, it likely represents a unique concept. Thus, it may share variance with job performance not shared with attitudes. We expected that engagement would therefore contribute incremental validity for predicting task and contextual performance.

\title{
Testing the Process Model
}

Finally, the proposition underlying our framework (Figure 1) is that engagement mediates the relations between antecedents and job performance. Based on Kahn (1990) and Macey and Schneider (2008), we expected that contextual factors and personal traits would relate to individuals' investment of their selves into their work roles, which should lead to higher levels of performance. Thus, we used meta-analytic path modeling to examine a model that included job characteristics, leadership, and dispositional constructs as distal variables, engagement as an endogenous proximal variable, and task and contextual performance as outcomes. In selecting variables, we chose those that were available in the literature and most accurately represented Macey and Schneider's (2008) framework. We included as many “core” motivational job characteristics (Fried \& Ferris, 1987) as possible because of their proximal relation to work tasks (Humphrey et al., 2007), as well as transformational leadership, conscientiousness, and positive affect.

\author{
Method \\ Literature Search \\ An extensive search was conducted to identify as many published and unpublished \\ studies as possible. The process involved a search of computerized databases from 1990 to April \\ of 2010. Databases utilized in the search included the following: ABI/Inform, EBSCO, \\ ProQuest, PsycInfo, JSTOR, Google Scholar, Social Sciences Citation Index, and Web of
}


Science. The search included the terms job, work, employee, physical, emotional, cognitive, vigor, dedication, and absorption, with the keyword engagement. We also conducted a manual search of major journals (e.g., Journal of Applied Psychology, Academy of Management Journal, Personnel Psychology, Journal of Organizational Behavior) as well as the reference lists of pertinent articles on work engagement. Finally, we collected unpublished dissertations and conference presentations and emailed authors of published research on engagement to obtain any unpublished work. This process resulted in over 200 published and over 30 unpublished articles. Primary Inclusion Criteria and Coding Procedures

We included all studies that contained a measure of engagement, described below. In addition, for inclusion a study must (a) have provided the necessary data to compute a correlation between a measure of engagement and at least one of our constructs of interest, and (b) be at the individual level. The aforementioned criteria reduced our initial population to 91 studies (80 published) resulting in 770 effect sizes.

All studies were double-coded by the authors, with an initial agreement of 94 percent, resolved to 100 percent agreement after discussion. When multiple effect sizes for a given sample were reported, a sample size weighted average was computed to generate a single data point for each construct (cf. Hunter \& Schmidt, 2004). We utilized the construct definitions discussed earlier in coding the job attitudes and antecedents; however, because of the importance of our coding decisions for engagement and job performance, we next describe these in detail.

Engagement. We used two main criteria when deciding which measures of engagement to include in our study. First, the measure had to refer to the actual work performed. Second, the measure had to refer to a psychological investment in the work, or in the performance of the work. As such, a measure of work engagement had to refer to a physical, emotional, and/or 
cognitive personal investment in one's work. As our analyses focus on the higher-order construct, we included measures with definitions and/or items associated with at least two of the conceptual dimensions of work engagement: physical (i.e., energetic, resilient, vigorous), emotional (i.e., emotionally attached or dedicated to one's work or job performance), and cognitive (i.e., cognitively focused, absorbed, vigilant). For a list of measures included, we refer the reader to Table 1 .

Job performance. We divided job performance into the classification system referred to by Borman \& Motowidlo (1993) of task and contextual performance. Task performance was defined as "the effectiveness with which job incumbents perform activities that contribute to the organization's technical core" (Borman \& Motowidlo, 1997, p. 99). Thus, any behavior that was related to the substantive tasks required by the job was included in this classification. Contextual performance was defined as performance that is not formally required as part of the job but that helps shape the social and psychological context of the organization (Borman \& Motowidlo, 1993). Related constructs like organizational citizenship behaviors (Organ, 1988) and extra-role performance (Van Dyne, Cummings, \& Parks, 1995) were also included. In order to code job performance, we used two decision rules, following Christian, Edwards, and Bradley (2010). First, we sorted the performance facets that utilized appropriate labels (i.e., task or contextual performance) into their respective categories. Next, for studies that did not report a label, we used the job title or item content to determine whether the rating was task or contextual.

\section{Meta-analytic Calculations}

We used the RBNL meta-analysis procedure (Raju, Burke, Normand, \& Langlois, 1991). RBNL corrects for artifactual error (i.e., sampling error, unreliability of measures) using samplebased data as opposed to using artifact distributions. These procedures estimate appropriately 
defined standard errors for corrected correlations when sample-based artifact values are incorporated into the corrections. We used the equation from Burke and Landis (2003) to estimate the standard error of the mean corrected correlation, assuming a random effects model, which has more accurate Type I error rates and more realistic confidence intervals than a fixed effects model (e.g., Erez, Bloom, \& Wells, 1996; Overton, 1998). Confidence intervals provide an estimate of the variability of the corrected mean correlation due to sampling error (Hunter \& Schmidt, 2004). We also report credibility intervals, which indicate the extent that individual correlations varied for a particular analysis distribution across studies (Hunter \& Schmidt, 2004).

We corrected for unreliability using the information in primary studies where possible; however, no corrections for range restriction were made due to the unavailability of these data. When reliability information was not reported, we used sample-based estimates of internal consistency (Hunter \& Schmidt, 2004) for all constructs except other-rated task and contextual performance. Meta-analyses that include self- and other-ratings of performance should correct for the most appropriate sources of unreliability (e.g., Judge \& Bono, 2001). Thus, we corrected for unreliability in the other-rated criteria using interrater reliability, which accounts for more sources of error than internal consistency (Schmidt, Viswesvaran, \& Ones, 2000). For missing interrater reliability values, we used values from Christian et al. (2010); for task performance, .59 , and for contextual performance, .51 . For objective measures, we assumed perfect reliability. Moderator Analyses

We examined for evidence of moderators by examining the percentage of variance in the correlations accounted for by artifacts, which suggests moderation if less than $60 \%$ of the variance is accounted for when range restriction is not corrected (Horn, Caranikas-Walker, Prussia, \& Griffeth, 1992; Mathieu \& Zajac, 1990). The variance attributable to artifacts in the 
majority of our analyses was below $60 \%$, so we proceeded with our analyses of moderation where the number of studies $(k)$ was sufficient to do so (i.e., when each moderator category contained 2 or more studies). Cortina (2003) suggests that when moderators are present, an appropriate method is to break down the effect sizes into categories and test for differences. When the $95 \%$ confidence intervals between two mean correlations do not overlap for a given moderator test, this is evidence of support for moderation (Finkelstein, Burke, \& Raju, 1995).

Measure type. In order to examine differences among engagement measures, we compared the UWES (the most frequently-used measure) to other measures of engagement.

Study design. Typically, the magnitude of a correlation decreases as the length of time between measurements increases (Nunnally \& Bernstein, 1994). Thus, lagged studies should have lower correlations than concurrent studies. We were also interested in whether relations differed between- and within-persons. Because within-person studies account for more sources of variation, we expected they would have stronger correlations than between-person designs.

Rater type. We also examined whether the type of rater of performance would influence the results. We expected that other-ratings would be subjected to fewer biases associated with leniency and common method variance than self-ratings of performance (Holzbach, 1978;

Podsakoff, MacKenzie, Lee, \& Podsakoff, 2003), and would have lower correlations than selfratings.

Publication bias. In order to assess the possibility that publication bias (Rosenthal, 1979) influenced our results, we classified studies as either published or unpublished.

Results

\section{Descriptive Information}


Table 2 presents sample-weighted mean reliability coefficients. Specific information on meta-analytic findings is reported in Tables 3-8. A corrected mean correlation (i.e., $M_{\rho}$ ) is statistically significant at the $p<.05$ level when its $95 \%$ confidence interval does not include zero within its bounds. Unless reported otherwise, confidence intervals did not include zero.

\section{Discriminant Validity with Job Attitudes}

Table 3 reports the correlations of engagement with job attitudes. Engagement was positively related to job satisfaction $\left(M_{\rho}=.53\right)$, organizational commitment $\left(M_{\rho}=.59\right)$, and job involvement $\left(M_{\rho}=.52\right)$. As expected, no relations were approaching unity (no 95\% CI included 1.0), indicating discriminant validity (see Anderson \& Gerbing, 1988; Harter \& Schmidt, 2008).

\section{Antecedents}

Job characteristics. Table 4 shows that, as expected, engagement was positively related to autonomy $\left(M_{\rho}=.39\right)$, task variety $\left(M_{\rho}=.53\right)$, task significance $\left(M_{\rho}=.51\right)$, feedback $\left(M_{\rho}=.33\right)$, problem solving $\left(M_{\rho}=.28\right)$, job complexity $\left(M_{\rho}=.24\right)$, and social support $\left(M_{\rho}=.32\right)$. Also as expected, engagement was negatively related to physical demands $\left(M_{\rho}=-.23\right)$ and work conditions $\left(M_{\rho}=-.22\right)$.

Leadership. Table 4 shows that, as expected, engagement was positively related to transformational leadership $\left(M_{\rho}=.27\right)$ and leader-member exchange $\left(M_{\rho}=.31\right)$.

Dispositional characteristics. Table 4 shows that, as expected, engagement was positively related to conscientiousness $\left(M_{\rho}=.42\right)$, positive affect $\left(M_{\rho}=.43\right)$, and proactive personality $\left(M_{\rho}=.44\right)$.

\section{Consequences}


Task and contextual performance. Table 4 shows that, as expected, engagement was positively related to task performance $\left(M_{\rho}=.43\right)$, and contextual performance $\left(M_{\rho}=.34\right)$.

\section{Moderator Analyses}

For the moderator analyses of engagement measure (Table 5), all 95\% CIs overlapped, with the exception of contextual performance. In this case, other measures had a significantly stronger relationship with contextual performance $\left(M_{\rho}=.48\right)$, than the UWES $\left(M_{\rho}=.31\right)$. For the analyses of study design, (Table 6), all 95\% CIs overlapped. For the analyses of rater type (Table 7), in all cases, 95\% CIs overlapped. Finally, for the analyses of publication bias (Table 8), all 95\% CIs overlapped, except for social support which had a stronger correlation for unpublished $\left(M_{\rho}=.46\right)$ versus published $\left(M_{\rho}=.31\right)$.

\section{Meta-analytic Correlation Matrix}

In order to analyze (a) the incremental validity of engagement and (b) the path model, we generated correlation matrices containing corrected correlations between each variable. Table 9 presents the intercorrelations among the variables used in the analyses of incremental validity. We computed the harmonic mean $\left(\mathrm{N}_{\mathrm{h}}\right)$ for each input matrix (Viswesvaran \& Ones, 1995). For the analysis of incremental validity for task performance, the $\mathrm{N}_{\mathrm{h}}$ was 3698 , for incremental validity for contextual performance, the $\mathrm{N}_{\mathrm{h}}$ was 3191 , and for the path model, the $\mathrm{N}_{\mathrm{h}}$ was 1091 . In order to minimize common-method and leniency bias concerns, all matrices were computed using estimates for other-rated (i.e., not self-rated) task and contextual performance. Also, we were unable to generate correlations for all of the cells due to unavailability of the data in our primary studies. Thus, we used assumed population estimates of these relationships (e.g., Colquitt, LePine, \& Noe, 2000; Harrison, Newman, \& Roth, 2002; Viswesvaran \& Ones, 1995). We provide information on the sources used for each of the population estimates below Table 9. 
Incremental Validity of Engagement for Predicting Task and Contextual Performance

Table 10 presents the results of the multiple regression analysis of the incremental validity of engagement for predicting task performance over job attitudes. We entered job satisfaction (JS), organizational commitment (OC), and job involvement (JI) in the first step, followed by engagement in the second step. The standardized regression coefficients for JS (.33) and JI (-.06) were significant $(p<.001)$ in step 1 , and explained a significant proportion of variance in task performance $\left(R^{2}=.11, p<.001\right)$. OC was not significant. However, in step 2, engagement $(\beta=.43, p<.001)$ explained incremental variance, as the change in $R^{2}$ was significant $\left(\Delta R^{2}=.19, p<.001\right)$.

Table 10 also presents the results of the regression analysis of the incremental validity of engagement for predicting contextual performance over job attitudes. We entered JS, OC, and JI in the first step, followed by engagement in a second step. At step 1, the standardized regression coefficients for JS (.14) and JI (.17) were significant $(\mathrm{p}<.001)$, and OC (.03) was significant at $p$ $<.05$. Step 1 explained a significant proportion of variance in contextual performance $\left(R^{2}=.05\right.$, $p<.001)$. In step 2 , engagement $(\beta=.44, p<.001)$ explained incremental variance, as the change in $R^{2}$ was significant $\left(\Delta R^{2}=.16, p<.001\right)$.

Meta-Analytic Path Model

Table 11 presents the meta-analytic correlations among the variables in the path model. We sequentially tested two nested models, beginning with our hypothesized full mediation model, which specifies job characteristics, transformational leadership, and personality characteristics as exogenous, engagement as an endogenous mediator, and task and contextual performance as endogenous outcomes. Because job characteristics are related with each other and with perceptions of transformational leadership (e.g., Piccolo \& Colquitt, 2006) we allowed 
each of these exogenous variables to correlate, as well as the disturbance terms for task and contextual performance, consistent with past research (Piccolo \& Colquitt, 2006). We first evaluated the full mediation model using the comparative fit index (CFI) and the root mean squared residual (RMSR), which are typically considered to be indicators of adequate fit when the CFI is less than or equal to .90 and the RMSR is less than or equal to .08 (Browne \& Cudeck, 1993; Mathieu, Gilson, \& Ruddy, 2006; Medsker, Williams, \& Holahan, 1994). The model showed moderate fit $\left(\chi^{2}(25)=679.80, p<.001 ; \mathrm{CFI}=.85 ; \mathrm{RMSR}=.10\right)$. However, previous studies have shown that transformational leadership is likely to have direct effects on task and contextual performance even when motivational characteristics are taken into account (Bono \& Judge, 2003; Piccolo \& Colquitt, 2006). Thus, after inspecting the model parameters, we freed direct paths between transformational leadership and the two performance variables. This final model (see Figure 2 ) fit the data better than the full mediation model $\left(\chi^{2}(23)=320.97 ; \chi^{2}\right.$ dif $=$ 358.88, $2 d f, p<.001 ; \mathrm{CFI}=.93 ; \mathrm{RMSR}=.08)$. Although modification indices suggested that freeing additional paths could improve the fit of the model, we retained this model because of its acceptable fit and parsimony.

\section{Discussion}

Our study attempted to provide resolution for several deficiencies in the engagement literature. Our goals were to find areas of commonality among studies of engagement in order to arrive at an agreed-upon definition, to demonstrate the uniqueness of this operationalization, and to clarify the nomological network of the constructs associated with work engagement. We found evidence that engagement is related to job performance, and that it appears to demonstrate incremental validity over job attitudes in predicting performance. Theoretical Contributions and Future Research Directions 
Our data suggest that Macey and Schneider's (2008) assertion appears to have merit: Rather than being merely a blend of old wines, engagement also has characteristics of new wines. Our evidence provides support for Macey and Schneider's (2008) prediction that these attitudes would correlate with engagement around $r=.50$, suggesting that work engagement is unique although it shares conceptual space with job attitudes. Interestingly, our results for otherrated task performance $(\rho=.39)$, when compared with meta-analytic estimates for job satisfaction ( $\rho=.30 ;$ Judge, Thoresen, Bono, \& Patton, 2001) and organizational commitment $(\rho$ $=.18$; Riketta, 2002) suggest that engagement relates to performance with a similar magnitude. However, our finding that engagement has incremental criterion-related validity over these attitudes adds to the reasoning that engagement's conceptual space is somewhat different. Thus, the extent to which individuals invest their "full selves" in the execution of their work appears to be a different concept from the extent to which individuals value their organizations or are satisfied with their jobs.

One way that engagement differs conceptually from many traditional attitudes is that it is closely aligned with task-specific motivation, which helps to explain why it was related equally strongly with task performance and contextual performance. This finding is at odds with the belief that engagement is predominantly associated with extra-role behaviors (e.g., Macey \& Schneider, 2008). Because engaged employees experience a high level of connection with their work tasks, they strive towards task-related goals that are intertwined with their in-role definitions and scripts, leading to high levels of in-role performance. Despite this, our findings also suggest that engaged employees are also likely to perform extra-role behaviors, perhaps because they are able to "free up" resources by accomplishing goals and performing their tasks efficiently, enabling them to pursue activities that are not part of their job descriptions. Another 
possibility is that engaged employees consider all aspects of work to be part of their domain, and thus they step outside of their roles to work toward goals held by coworkers and the organization. These viewpoints suggest alternative explanations for the relations between engagement and task and contextual performance. Future research could investigate whether engagement simultaneously leads to task and contextual performance, or whether engaged employees tend to prioritize in-role tasks.

Regarding the "state versus trait" debate, our findings were inconclusive. Consistent with past research on state versus trait conceptualizations of positive and negative affect (Thoresen et al., 2003), we did not find significant differences between studies of "engagement in general" versus "in the moment." Given that most of these analyses were conducted on very few studies, our results should be interpreted with caution. What we can conclude from our data, however, is that there is a dearth of research on within-person engagement, and that future studies should use experience-sampling methods to determine the extent to which within- and between-person methods may differ. For example, if engagement fluctuates over time, it could have stronger momentary relations with performance such that high engagement on a particular day leads to high performance on that same day. Also, future research could be conducted to uncover whether engagement is indeed a stable dispositional trait by using longitudinal designs to track engagement within-persons across years and jobs, and by controlling for conscientiousness, positive affect, and proactive personality.

We also found initial, tentative support for the idea that engagement partially mediates the relations between distal factors and job performance. However, we do note that the path weights for autonomy, feedback, and transformational leadership were near zero in terms of their relations with engagement in our final model, implying that the practical importance of these 
variables may be minimal when other factors are taken into account. Moreover, we did not test alternative models specifying different causal ordering of the variables because we were limited by the cross-sectional nature of our data. Thus, we can only tentatively conclude that our framework appropriately specified the causal direction of relationships. However, our moderator analyses demonstrated that engagement was related to all of the available antecedents and consequences when assessed in time-lagged designs. Given that the majority of studies were assessed concurrently, however, future research should be conducted using lagged designs that can better enable causal inferences. Related to this, it is possible that reverse, or reciprocal, causality is an alternative explanation for the relations between engagement and some factors in our model, such as contextual performance and social support. For example, as workers become more willing to engage in behaviors that facilitate the social context, they are also creating an environment conducive to further engagement of their peers (i.e., increasing social support). In a similar vein, engagement has been shown to increase other job characteristics such as perceived autonomy (Llorens, Schaufeli, Bakker, \& Salanova, 2007). Future research could investigate this possibility with intervention studies designed to increase engagement, and measuring how factors conceptualized as antecedents may increase as a result of increases in engagement.

The present investigation also helps to clarify the role of engagement as a motivational construct that is related to contextual and self-based factors. First, we add work engagement to the range of motivational factors that are related to work characteristics, as suggested by job characteristics theory (Hackman \& Oldham, 1976). This suggests that work engagement is to some degree aligned with the motivating potential of the work context, and can be facilitated through job design. However, as we note above, our path model suggests that only task variety and significance appear to be related with engagement, as autonomy and feedback were not 
strongly related with engagement in the final model. This finding might indicate that work engagement is more strongly related to job characteristics that are associated with the perception of meaningfulness of the work itself, which Kahn (1990) notes is a precursor to engagement. Task significance and task variety are both thought to impact an individual's perception of the meaningfulness of their work (Hackman \& Oldham, 1976). Conversely, autonomy and feedback lead to perceptions of experienced responsibility and knowledge of results rather than to meaningfulness (Humphrey et al., 2007). Future research concerning the differential effects of job characteristics on engagement could help to shed light on this issue.

Second, we found tentative evidence that leadership was related to engagement. However, the results of our path model suggested that at best, leadership is only weakly related to engagement when other factors are taken into account. It is possible that other processes might account for the relation between leadership and performance (i.e., changes in basic values or beliefs; Podsakoff, Mackenzie, Moorman, \& Fetter, 1990). It is also possible that there are moderator variables, such as trust in leadership or psychological safety, which might influence the relation between leadership and engagement (Macey \& Schneider, 2008). Thus, future research could investigate whether the extent to which individuals feel that it is "safe to engage" in the work (Kahn, 1990) increases the relation between leadership and engagement.

Third, our findings are consistent with research suggesting that more proximal states and motivation can explain the relation between personality and performance (Barrick, Stewart, \& Piotrowski, 2002; Judge \& Ilies, 2002). It remains unclear, however, the extent to which perceived job characteristics or leadership could moderate the extent to which dispositional factors will relate to engagement (e.g., Macey \& Schneider, 2008). Future studies could 
investigate whether certain personality traits might not relate to engagement when jobs are demanding or have little intrinsic meaning.

Future research could also broaden the range of antecedents to engagement. For example, two aspects of person-environment (P-E) fit are especially relevant: Demands-abilities fit, or congruence between job demands and employee abilities, and needs-supplies fit, or congruence between employee needs and the rewards a job supplies (Cable \& DeRue, 2002). Because engagement reflects employees' investment of their whole selves into their work, it is likely that demands-abilities fit and needs-supplies fit perceptions are important cognitive precursors to employees' willingness to make that investment. Given the findings of the present study, and observed relations between needs-supplies fit and contextual performance (Cable \& DeRue, 2002) and between demands-abilities and task performance (Greguras \& Diefendorff, 2009), it also seems likely that engagement serves as a mediator in the P-E fit-performance relationship. We therefore recommend that researchers consider these aspects of P-E fit in future research on engagement. Further, research could examine the possibility of reciprocal relations between fit perceptions and engagement. Engaged workers, after fully investing themselves in their jobs, may begin to develop a sense of P-E fit that is stronger than it was previously, by increasing or changing their abilities to meet the demands of the job, by adjusting their needs to be satisfied by what the job supplies, or by actively changing the job itself to one that is a better fit for them.

Future research should also address how engagement fits in with other theories of motivation such as goal setting or self-regulation theories. For example, work engagement could explain why individuals stay committed to goals, or alternatively, how goal-setting could lead to engagement. Also, though the literature on self-regulation suggests that motivation may be depleted through factors that limit cognitive resources (e.g., Muraven \& Baumeister, 2000), few 
studies have considered engagement from this perspective (for an exception, see Sonnentag, 2003).

\section{Practical Implications}

Our findings also have potential implications for practice. First, using the defining features of work engagement, which we have shown adequately differentiate from conceptualizations of more traditional job attitudes, practitioners may be able to augment their methodologies for assessing the capability and motivation of workers. As such, practitioners can use the guidelines that we have specified to develop more consistent measures that focus on the defining elements of engagement.

Second, we have illustrated that engagement might indeed help employers to improve or maintain their competitive advantage. Our results show that engagement has significant relations with in-role and discretionary work performance. In terms of task performance, this signals that an engaged workforce will likely perform their tasks more efficiently and effectively. In terms of discretionary behaviors, this means that employees, when engaged, will be more likely to create a social context that is conducive to teamwork, helping, voice, and other important discretionary behaviors that lead to organizational effectiveness (Podsakoff, Whiting, \& Podsakoff, 2009).

Third, practitioners should attempt to support and cultivate engagement in their workforce. Our study suggests at least two ways that managers can improve the engagement of their workers, through selection and job design. Importantly, organizations should ideally attend to more than one of these methods of improvement, because one might not be sufficient alone (Macey \& Schneider, 2008). First, organizations might attempt to hire employees predisposed to engagement by selecting individuals with high conscientiousness, proactivity, and positive affect. However, selecting for these traits might not be enough, because of the likelihood that 
employees can only be as engaged as the work itself allows for. Thus, managers might be able to increase engagement by designing jobs that include motivating characteristics, particularly with regard to the significance and variety of the tasks performed. This way, managers might be able to "set the stage for engagement" by creating contextual conditions that facilitate employees' perceptions of meaningful work.

\section{Limitations}

Our study had several limitations. First, the vast majority of the studies that we found assessed variables using concurrent methods. Although our moderator analysis failed to show differences between methods, given the small number of studies that were not concurrent, the data are not conclusive. This is especially distressing, given that the question of within-person versus between-person measurement is paramount in developing a conceptual understanding of engagement as a state versus as an enduring condition. Second, the majority of studies used selfreport methods, which could have inflated the correlations among the variables. Third, the quality of studies contained in the meta-analysis may have had a systematic impact on the observed effect sizes. However, in our moderator analyses of publication bias, we did not find consistent evidence that this was true.

Fourth, there were limitations associated with our use of meta-analytic regression and path analysis. In some cases there were no correlations in our dataset for the relationships among the variables in the correlation matrices; instead we used estimates taken from other studies, and thus, other samples. This raises the possibility that the magnitudes of the effects in some cells might not be generalizable to the sample populations in the other cells. However, when possible we used sample-based estimates derived from our primary studies, and when not possible, we 
attempted to use estimates based on large samples from other meta-analyses to minimize sampling error. However, these results should be interpreted with caution, and future studies should attempt to replicate our path analyses using single-sample studies. Also, each cell in the path-analysis and regression analyses was based on different sample sizes, so we chose to use the harmonic mean, a conservative estimate of sample size (Ones, Viswesvaran, \& Reiss, 1996). However, this estimate was higher than the actual sample size in a few cells, potentially leading to the underestimation of sampling error (Colquitt, LePine, \& Noe, 2000). Finally, our metaanalysis was limited to a small number of data points in some analyses, which made the testing of some moderators impossible (e.g., Sackett, Harris, \& Orr, 1986). Although several moderators that we investigated accounted for the variability among correlations, many analyses still indicated heterogeneity. Although this is often the case in meta-analyses (Cortina, 2003), future research may be needed to uncover the variables causing the observed variability in effect sizes.

\section{Conclusion}

As is common in emerging areas of research, engagement research has undergone growing pains. Although conceptualizations drawing on Kahn (1990) appear to represent a somewhat unique and useful addition to the organizational literature, we found areas that can still use improvement. Engagement research can benefit from methodological refinements, especially with regard to time: lagged designs and within-person studies need to be conducted to better understand state engagement, and longitudinal research might shed light on trait engagement. Also, future research should continue to expand its nomological network, in particular with regards to work-related criteria (e.g., workplace deviance, workplace safety, creativity, or adaptive performance). Efforts such as these should be undertaken, because, as our study suggests, work engagement is a useful construct meriting further attention. 
1

2

3

4

5

6

7

8

9

10

11

12

13

14

15

16

17

18

19

20

21

22

23

24

25

26

27

28

29

30

31

32

33

34

35

36

37

38

39

40

41

42

43

44

45

46

47

48

49

50

51

52

53

54

55

56

57

58

59

60 


\section{References}

References marked with an asterisk (*) indicate studies that contributed data to the meta-analysis

*Alarcon, G. (2009). The development of the Wright Work Engagement Scale. Unpublished doctoral dissertation, Wright State University, Dayton, $\mathrm{OH}$.

Anderson, J. C., \& Gerbing, D. W. (1988). Structural equation modeling in practice: A review and recommended two-step approach. Psychological Bulletin, 103, 411-423.

*Andreassen, C. S., Ursin, H., \& Eriksen, H. R. (2007). The relationship between strong motivation to work, "workaholism", and health. Psychology \& Health, 22, 615-629.

Ashforth, B. E., \& Humphrey, R. H. (1995). Emotion in the workplace: A reappraisal. Human Relations, 48, 97-125.

*Avey, J. B., Wernsing, T. S., \& Luthans, F. (2008). Can positive employees help positive organizational change? Impact of psychological capital and emotions on relevant attitudes and behaviors. The Journal of Applied Behavioral Science, 44, 48-70.

Bakker, A. B. (2005). Flow among music teachers and their students: The crossover of peak experiences. Journal of Vocational Behavior, 66, 26-44.

*Bakker, A. B., \& Bal, M. (2010). Weekly work engagement and performance: A study among starting teachers. Journal of Occupational and Organizational Psychology, 83, 189-206.

*Bakker, A. B., \& Demerouti, E. (2009). The crossover of work engagement between working couples. Journal of Managerial Psychology, 24, 220-236.

*Bakker, A. B., Demerouti, E., \& Schaufeli, W. B. (2005). The crossover of burnout and work engagement among working couples. Human Relations, 58, 661-689.

*Bakker, A. B., Demerouti, E., \& Verbeke, W. (2004). Using the job demands-resources model to predict burnout and performance. Human Resource Management, 43, 83-104. 
*Bakker, A. B., \& Geurts, S. A. E. (2004). Toward a dual-process model of work-home interference. Work and Occupations, 31, 345-366.

*Bakker, A. B., Hakanen, J. J., Demerouti, E., \& Xanthopoulou, D. (2007). Job resources boost work engagement, particularly when job demands are high. Journal of Educational Psychology, 99, 274-284.

*Bakker, A. B., \& Heuven, E. (2006). Emotional dissonance, burnout, and in-role performance among nurses and police officers. International Journal of Stress Management, 13, 423440.

*Bakker, A.B., van Emmerik, H., \& Euwema, M.C. (2006). Crossover of burnout and engagement in work teams. Work and Occupations, 33, 464-489.

*Bakker, A. B., \& Xanthopoulou, D. (2009). The crossover of daily work engagement: Test of an actor-partner interdependence. Journal of Applied Psychology, 94, 1562-1571.

Bandura, A. (2001). Social cognitive theory: An agentic perspective. Annual Review of Psychology, 52, 1-26.

Barrick, M. R., \& Mount, M. K. (1993). Autonomy as a moderator of the relationships between the big five personality dimensions and job performance. Journal of Applied Psychology, 78, 111-118.

Barrick, M. R., Mount, M., K., \& Strauss, J. P. (1993). Conscientiousness and performance of sales representatives: Test of the mediating effects of goal setting. Journal of Applied Psychology, 78, 715-722.

Barrick, M., Stewart, G., \& Piotrowski, M. (2002). Personality and job performance: Test of the mediating effects of motivation among sales representatives. Journal of Applied Psychology, 87, 43-51. 
Bass, B. M., \& Avolio, B. (1990). Transformational leadership development: Manual for the Multifactor Leadership Questionnaire. Palo Alto, CA: Consulting Psychologist Press.

Bateman, T., \& Crant, J. (1993). The proactive component of organizational behavior: A measure and correlates. Journal of Organizational Behavior, 14, 103-118.

*Beckers, D. G. J., Van der Linden, D., Smulders, P. G. W., Kompier, M. A. J., Van Veldhoven, J. P. M., \& Van Yperen, N. W. (2004). Working overtime hours: Relations with fatigue, work motivation, and the quality of work. Journal of Occupational and Environmental Medicine, 46, 1282-1289.

Bono, J. E., \& Judge, T. A. (2003). Self-concordance at work: Toward understanding the motivational effects of transformational leaders. Academy of Management Journal, 46, 554571.

Borman, W. C., \& Motowidlo, S. (1993). Expanding the criterion domain to include elements of contextual performance. In N. Schmitt \& W. Borman (Eds.), Personnel selection in organizations (Vol. 71, pp. 71-98). San Francisco: Jossey-Bass.

Borman, W. C., \& Motowidlo, S. (1997). Task performance and contextual performance: The meaning for personnel selection research. Human Performance, 10, 99-109.

Borman, W. C., Penner, L. A., Allen, T. D., \& Motowidlo, S. J. (2001). Personality predictors of citizenship performance. International Journal of Selection and Assessment, 9, 52-69.

*Bosman, J., Rothmann, S., Buitendach, J. H. (2005). Job insecurity, burnout and work engagement: The impact of positive and negative affectivity. South African Journal of Industrial Psychology, 31, 48-56.

Brief, A. P., \& Weiss, H. M. (2002). Organizational behavior: Affect in the workplace. Annual Review of Psychology, 53, 279-307. 
Brooke, P., Russell, D., \& Price, J. (1988). Discriminant validation of measures of job satisfaction, job involvement, and organizational commitment. Journal of Applied Psychology, 73, 139-145.

Brown, S. P. (1996). A meta-analysis and review of organizational research on job involvement. Psychological Bulletin, 120, 235-255.

Browne, M. W., \& Cudeck, R. (1993). Alternative ways of assessing model fit. In K. A. Bollen \& J. S. Long (Eds.), Testing structural equation models (pp. 136-162). Newbury Park, CA: Sage.

Burke, M. J. (2008). On the skilled aspect of employee engagement. Industrial and Organizational Psychology, 1, 70-71.

Burke, M. J., \& Landis, R. (2003). Methodological and conceptual challenges in conducting and interpreting meta-analyses. In K. Murphy (Ed.), Validity generalization: A critical review (pp. 287-309). Mahwah, NJ: Lawrence Erlbaum Associates.

Cable, D. M., \& DeRue, D. S. (2002). The convergent and discriminant validity of subjective fit perceptions. Journal of Applied Psychology, 87, 875-884.

Campbell, D., \& Fiske, D. (1959). Convergent and discriminant validation by the multitraitmultimethod matrix. Psychological Bulletin, 56, 81-105.

Campbell, S. M., Ward, A. J., Sonnenfeld, J. A., \& Agle, B. R. (2008). Relational ties that bind: Leader-follower relationship dimensions and charismatic attribution. Leadership Quarterly, 19, 556-568.

Campion, M. A. (1988). Interdisciplinary approaches to job design: A constructive replication with extensions. Journal of Applied Psychology, 73, 467-481. 
Christian, M. S., Edwards, B. D., \& Bradley, J. C. (2010). Situational judgment tests: Constructs assessed and a meta-analysis of their criterion-related validities. Personnel Psychology, 63, 83-117.

*Cinamon, R. G., Rich, Y., \& Westman, M. (2007). Teachers' occupation-specific work-family conflict. The Career Development Quarterly, 55, 249-261.

*Coetzer, C. F., \& Rothmann, S. (2007). Job demands, job resources, and work engagement of employees in a manufacturing organisation. Southern African Business Review, 11, 1732.

Colquitt, J., LePine, J., \& Noe, R. (2000). Toward an integrative theory of training motivation: A meta-analytic path analysis of 20 years of research. Journal of Applied Psychology, 85, $678-707$.

Connell, P. W. (2005). Transformational leadership, leader-member exchange (LMX), and OCB: The role of motives. Unpublished doctoral dissertation, University of South Florida, Tampa, FL.

Cortina, J. (2003). Apples and oranges (and pears, oh my!): The search for moderators in metaanalysis. Organizational Research Methods, 6, 415-439.

Crant, J. (1995). The proactive personality scale and objective job performance among real estate agents. Journal of Applied Psychology, 80, 532-537.

Dalal, R. S., Brummel, B. J., Wee, S., \& Thomas, L. L. (2008). Defining employee engagement for productive research and practice. Industrial and Organizational Psychology, 1, 52-55.

*De Cuyper, N., \& De Witte, H. (2005). Job insecurity: Mediator or moderator of the relationship between type of contract and various outcomes? South African Journal of Industrial Psychology, 31, 79-86. 
*De Lange, A. H., de Witte, H., \& Notelaers, G. (2008). Should I stay or should I go? Examining longitudinal relations among job resources and work engagement for stayers versus movers. Work \& Stress, 22, 201-223.

Demerouti, E. (1999). Burnout: Eine Folge konkreter Arbeitsbedingungen bei Dienstleistungsund Produktionstatigkeiten. [Burnout: A consequence of specific working conditions among human service, and production tasks]. Frankfurt/Main: Lang.

*Demerouti, E., Bakker, A. B., Nachreiner, F., Schaufeli, W. B. (2000). A model of burnout and life satisfaction amongst nurses. Journal of Advanced Nursing, 32, 454-464.

*Demerouti, E., Bakker, A. B., de Jonge, J., Janssen, P. P., \& Schaufeli, W. B. (2001). Burnout and engagement at work as a function of demands and control. Scandinavian Journal of Work and Environmental Health, 4, 279-286.

Demerouti, E., Bakker, A. B., Vardakou, I., \& Kantas, A. (2003). The convergent validity of two burnout instruments: A multitrait-multimethod analysis. European Journal of Psychological Assessment, 19, 12-23.

*Dikkers, J., Jansen, P., Lange, A., Vinkenburg, C., \& Kooij, D. (2010). Proactivity, job characteristics, and engagement: a longitudinal study. Career Development International, $15,59-77$.

Eagly, A. H., \& Chaiken, S. (1993). The psychology of attitudes. Fort Worth, TX: Harcourt Brace.

Engle, E. M., \& Lord, R. G. (1997). Implicit theories, self-schemas, and leader-member exchange. Academy of Management Journal, 40, 988-1010. 
Erez, A., Bloom, M., \& Wells, M. (1996). On a proper meta-analytic model for correlations: New approaches to situational specificity and validity generalization. Personnel Psychology, 49, 275-306.

Erickson, T. J. (2005). Testimony submitted before the U.S. Senate Committee on Health, Education, Labor and Pensions, May 26.

Felfe, J., \& Schyns, B. (2006). Personality and the perception of transformational leadership: The impact of extraversion, neuroticism, personal need for structure and occupational self efficacy. Journal of Applied Social Psychology, 36, 708-741.

Finkelstein, L. M.. Burke, M. J., \& Raju, N. S. (1995). Age discrimination in simulated employment settings: An integrative analysis. Journal of Applied Psychology, 80, 652663.

Fried, Y., \& Ferris, G. (1987). The validity of the job characteristics model: A review and metaanalysis. Personnel Psychology, 40, 287-322.

*Fritz, C., \& Sonnentag, S. (2005). Recovery, health, and job performance: Effects of weekend experiences. Journal of Occupational Health Psychology, 10, 187-199.

*Fritz, C., \& Sonnentag, S. (2006). Recovery, well-being, and performance-related outcomes: The role of workload and vacation experiences. Journal of Applied Psychology, 91, 936945.

Fuller, J. B., Marler, L. E., \& Hester, K. (2006). Promoting felt responsibility for constructive change and proactive behavior: Exploring aspects of an elaborated model of work design. Journal of Organizational Behavior, 27, 1089-1120.

Furnham, A., Petrides, K., Jackson, C., \& Cotter, T. (2002). Do personality factors predict job satisfaction? Personality and Individual Differences, 33, 1325-1342. 
*Gan, Y., Yang, M., Zhou, Y., \& Zhang, Y. (2007). The two-factor structure of future-oriented coping and its mediating role in student engagement. Personality and Individual Differences, 43, 851-863.

George, J. M. (2000). Emotions and leadership: The role of emotional intelligence. Human Relations, 53, 1027-1041.

Gersick, C. J. G., Bartunek, J. M., \& Dutton, J. E. (2000). Learning from academia: The importance of relationships in professional life. Academy of Management Journal, 43, 1026-1044.

Gerstner, C. R., Day, D. V. (1997). Meta-analytic review of leader-member exchange theory: Correlates and construct issues. Journal of Applied Psychology, 82, 827-844.

*Gill, D. S. (2007). Employee selection and work engagement: Do recruitment and selection practices influence work engagement? Unpublished doctoral dissertation: Kansas State University, Manhattan, Kansas.

*Gorgievski, M. J., Bakker, A. B., \& Schaufeli, W. B. (2010). Work engagement and workaholism: Comparing the self-employed and salaried employees. The Journal of Positive Psychology, 5, 83-96.

*Gorter R. C., te Brake H. J. H. M., Hoogstraten J., \& Eijkman M. A. J. (2008). Positive engagement and job resources in dental practice. Community Dentistry and Oral Epidemiology, 36, 47-54.

Graen, G., \& Scandura, T. (1987) Toward a psychology of dyadic organizing. In B. Staw \& L. L. Cummings (Eds.) Research in Organizational Behavior, 9, 175-208. Greenwich, Conn.: JAI Press. 
Greguras, G. J., \& Diefendorff, J. M. (2009). Different fits satisfy different needs: Linking person-environment fit to employee commitment and performance using selfdetermination theory. Journal of Applied Psychology, 94, 465-477.

Hackman, J. R., \& Oldham, G. R. (1976). Motivation through the design of work: Test of a theory. Organizational Behavior and Human Performance, 16, 250-279.

Hackman, J. R., \& Oldham, G. R. (1980). Work redesign. Reading, MA: Addison-Wesley.

*Hakanen, J. J., Bakker, A. B. \& Demerouti, E. (2005). How dentists cope with their job demands and stay engaged: The moderating role of job resources. European Journal of Oral Sciences, 113, 497-487.

*Hakanen, J. J., Bakker, A. B. \& Schaufeli, W. B. (2006). Burnout and work engagement among teachers. Journal of School Psychology, 43, 495-513.

*Hakanen, J. J., \& Lindbohm, M. J. (2008). Work engagement among breast cancer survivors and the referents: The importance of optimism and social resources at work. Journal of Cancer Survivorship, 2, 283-295.

*Hakanen, J. J., Perhoniemi, R., Toppinen-Tanner, S. (2008). Positive gain spirals at work: From job resources to work engagement, personal initiative and work-unit innovativeness. Journal of Vocational Behavior, 73, 78-91.

*Halbesleben, J. R. B., Demerouti, E. (2005). The construct validity of an alternative measure of burnout: Investigating the English translation of the Oldenburg Burnout Inventory. Work \& Stress, 19, 208-220.

*Halbesleben, J. R. B., Harvey, J., \& Bolino, M. C. (2009). Too engaged? A conservation of resources view of the relationship between work engagement and work interference with family. Journal of Applied Psychology, 94, 1452-1465. 
*Hallberg, U., Johansson, G., \& Schaufeli, W. B. (2007). Type A behavior and work situations: Associations with burnout and work engagement. Scandinavian Journal of Psychology, $48,135-142$.

*Hallberg, U., Schaufeli, W.B. (2006). “Same same” but different: Can work engagement be discriminated from job involvement and organizational commitment? European Journal of Psychology, 11, 119-127.

Harrison, D., Newman, D., \& Roth, P. (2002). How important are job attitudes? Meta-analytic comparisons of integrative behavioral outcomes and time sequences. The Academy of Management Journal, 49, 305-325.

Harter, J. K., \& Schmidt, F. L. (2008). Conceptual versus empirical distinctions among constructs: Implications for discriminant validity. Industrial and Organizational Psychology, 1, 36-39.

Harter, J., Schmidt, F., \& Hayes, T. (2002). Business-unit-level relationship between employee satisfaction, employee engagement, and business outcomes: A meta-analysis. Journal of Applied Psychology, 87, 268-279.

Hirschfeld, R. R., \& Thomas, C. H. (2008). Representations of trait engagement: Integration, additions, and mechanisms. Industrial and Organizational Psychology, 1, 63-66.

*Heuvel, M., Demerouti, E., Schreurs, B., Bakker, A., \& Schaufeli, W. B. (2009). Does meaning-making help during organizational change? Development and validation of a new scale. Career Development International, 14, 508-533.

Holzbach, R. L. (1978). Rater bias in performance ratings: Superior, self, and peer ratings. Journal of Applied Psychology, 63, 579-588. 
Horn, P. W., Caranikas-Walker, F., Prussia, G. E. \& Griffeth, R. E. (1992). A meta-analytical structural equations analysis of a model of employee turnover. Journal of Applied Psychology, 77, 890-909.

Howell, J. M., \& Hall-Merenda, K. (1999). The ties that bind: The impact of leader-member exchange, transformational and transactional leadership, and distance on predicting follower performance. Journal of Applied Psychology, 84, 680-694.

Humphrey, S. E., Nahrgang, J. D., \& Morgeson, F. P. (2007). Integrating motivational, social, and contextual work design features: A meta-analytic summary and theoretical extension of the work design literature. Journal of Applied Psychology, 92, 1332-1356.

Hunter, J., \& Schmidt, F. (2004). Methods of meta-analysis: Correcting error and bias in research findings. Newbury Park, CA: Sage Publications.

Ilies, R., \& Judge, T. A. (2002). Understanding the dynamic relationships among personality, mood, and job satisfaction: A field experience sampling study. Organizational Behavior and Human Decision Processes, 89, 1119-1139.

*Inoue, A., Kawakami, N., Ishizaki, M., Shimazu, A., Tsuchiya, M., Tabata, M., et al. (2010). Organizational justice, psychological distress, and work engagement in Japanese workers. International Archives of Occupational and Environmental Health, 83, 29-38.

*Jackson, L. T. B., Rothmann, S., \& van de Vivjer, F. J. R. (2006). A model of work-related well-being for educators in South Africa. Stress \& Health, 22, 263-274.

*Jezzi, M. M. (2006). The moderating role of optimism as related to work resources and work engagement. Unpublished doctoral dissertation: San Jose State University, San Jose, CA. 
Judge, T. A., \& Bono, J. E. (2001). Relationship of core self-evaluations traits—self-esteem, generalized self-efficacy, locus of control, and emotional stability—with job satisfaction and job performance: A meta-analysis. Journal of Applied Psychology, 86, 80-92.

Judge, T., \& Ilies, R. (2002). Relationship of personality to performance motivation: A metaanalytic review. Journal of Applied Psychology, 87, 797-807.

Judge, T. A., \& Piccolo, R. (2004). Transformational and transactional leadership: A meta-analytic test of their relative validity. Journal of Applied Psychology, 89, 755-768.

Judge, T. A., Thoresen, C. J., Bono, J. E., \& Patton, G. K. (2001). The job satisfaction-job performance relationship: A qualitative and quantitative review. Psychological Bulletin, $127,376-407$.

Kahn, W. A. (1990). Psychological conditions of personal engagement and disengagement at work. Academy of Management Journal, 33, 692-724.

Kahn, W. A. (1992). To be fully there: Psychological presence at work. Human Relations, 45, 321-349.

Kanfer, R. (1990). Motivation and individual differences in learning: An integration of developmental, differential and cognitive perspectives. Learning and Individual Differences, 2, 221-239.

Kanungo, R. N. (1982). Measurement of job and work involvement. Journal of Applied Psychology, 67,341-349.

*Karatepe, O. M., \& Olugbade, O. A. (2009). The effects of job and personal resources on hotel employees' work engagement. International Journal of Hospitality Management, 28, 504-512.

Kelley, T. L. (1927). Interpretation of educational measurements. New York, NY: World Book. 
*Kim, H. J., Shin, K. H., \& Swanger, N. (2009). Burnout and engagement: A comparative analysis using the Big Five personality dimensions. International Journal of Hospitality Management, 28, 96-104.

*Kinnunen, U., Feldt, T., \& Mäkikangas, A. (2008). Testing the effort-reward imbalance model among Finnish managers: The role of perceived organizational support. Journal of Occupational Health Psychology, 13, 114-127.

*Kuhnel, J., Sonnentag, S., \& Westman, M. (2009). Does work engagement increase after a short respite? The role of job involvement as a double-edged sword. Journal of Occupational and Organizational Psychology, 82, 575-594.

*Langelaan, S., Bakker, A. B., Van Doornen, L. J. P., \& Schaufeli, W. B. (2006). Burnout and work engagement: Do individual differences make a difference? Personality and Individual Differences, 40, 521-532.

*Lee, K. E., \& Shin, K. H. (2005). Job burnout, engagement and turnover intention of dietitians and chefs at a contract foodservice management company. Journal of Community Nutrition, 7, 100-106.

LePine, J. A., Erez, A., \& Johnson, D. E. (2002). The nature and dimensionality of organizational citizenship behavior: A critical review and meta-analysis. Journal of Applied Psychology, 87, 52-65.

*Little, L. M., Simmons, B. L., Nelson, D. L. (2007). Health among leaders: Positive and negative affect, engagement, and burnout, forgiveness and revenge. Journal of Management Studies, 44, 243-260. 
*Llorens, S, Schaufeli, W., Bakker, A.B., \& Salanova, M. (2007). Does a positive gain spiral of resources, efficacy beliefs and engagement exist? Computers in Human Behavior, 23, 825-841.

*Llorens, S., Bakker, A. B., Schaufeli, W. B., \& Salanova, M. (2006). Testing the robustness of the job demands-resources model. International Journal of Stress Management, 13, 378391.

Lodahl, T. M., \& Kejner, M. (1965). The definition and measurement of job involvement. Journal of Applied Psychology, 49, 24-33.

Macey, W., \& Schneider, B. (2008). The meaning of employee engagement. Industrial and Organizational Psychology, 1, 3-30.

*Marjanovic, Z., Greenglass, E. R., \& Coffey, S. (2007). The relevance of psychosocial variables and working conditions in predicting nurses' coping strategies during the SARS crisis: An online questionnaire survey. International Journal of Nursing Studies, 44, 991-998.

Maslach, C., Schaufeli, W. B., \& Leiter, M. (2001). Job Burnout. Annual Review of Psychology, 52, 397-422.

Mathieu, J. E., Gilson, L. L. \& Ruddy, T. M. (2006). Empowerment and team effectiveness: An empirical test of an integrated model. Journal of Applied Psychology, 91, 97-108.

Mathieu, J. E., \& Zajac, D. (1990). A review and meta-analysis of the antecedents, correlates, and consequences of organizational commitment. Psychological Bulletin, 108, 171-194.

*Mauno, S., Kinnunen, U., \& Ruokolainen, M. (2007). Job demands and resources as antecedents of work engagement: A longitudinal study. Journal of Vocational Behavior, $70,149-171$. 
*Mauno, S., Kinnunen, U., Mäkikangas, A., \& Nätti, J. (2005). Psychological consequences of fixed-term employment and perceived job insecurity among health care staff. European Journal of Work \& Organizational Psychology, 14, 209-237.

*May, D. R., Gilson, R. L., \& Harter, L. M. (2004). The psychological conditions of meaningfulness, safety and availability and the engagement of the human spirit at work. Journal of Occupational and Organizational Psychology, 77, 11-37.

Medsker, G. J., Williams, L. J., \& Holahan, P. J. (1994). A review of current practices for evaluating causal models in organizational behavior and human resource management research. Journal of Management, 20,439-464.

*Moliner, C., Martínez-Tur, V., Ramos, J., Peiró, J. M., \& Cropanzano, R. (2007). Organizational justice and extra-role customer service: The mediating role of well-being at work. European Journal of Work and Organizational Psychology, 17, 327-348.

*Montgomery, A. J., Peeters, M. C. W., Schaufeli, W. B., \& Den Ouden, M. (2003). Work-home interference among newspaper managers: Its relationship with burnout and engagement. Anxiety, Stress, and Coping, 16, 195-211.

*Moss, S. (2009). Cultivating the regulatory focus of followers to amplify their sensitivity to transformational leadership. Journal of Leadership \& Organizational Studies, 15, 241259.

*Mostert, K. (2006). Work-home interaction as partial mediator between job resources and work engagement. Southern African Business Review, 10, 53-74.

*Mostert, K., Cronje, S., \& Pienaar, J. (2006). Job resources, work engagement and the mediating role of positive work-home interaction of police officers in the North West Province. Acta Criminoligica, 19, 64-87. 
*Mostert, K., \& Rathbone, A. D. (2007). Work characteristics, work-home interaction and engagement of employees in the mining industry. Management Dynamics, 16, 36-52.

*Mostert, K., \& Rothmann, S. (2006). Work-related well-being in the South African police service. Journal of Criminal Justice, 34, 479-491.

Mowday, R. (1998). Reflections on the study and relevance of organizational commitment. Human Resource Management Review, 8, 387-401.

Munz, D. C., Huelsman, T. J., Konold, T. R., \& McKinney, J. J. (1996). Are there methodological and substantive roles for affectivity in Job Diagnostic Survey relationships? Journal of Applied Psychology, 81, 795-805.

Muraven, M., \& Baumeister, R. F. (2000). Self-regulation and depletion of limited resources: Does self-control resemble a muscle? Psychological Bulletin, 126, 247-259.

Newman, D. A., \& Harrison, D. A. (2008). Been there, bottled that: Are state and behavioral work engagement new and useful construct "wines"? Industrial and Organizational Psychology, 1, 31-35.

Nunnally, J. C., \& Bernstein, I. H. (1994). Psychometric theory ( $3^{\text {rd }}$ ed.). New York: McGrawHill.

*Olivier, A. L., \& Rothmann, S. (2007). Antecedents of work engagement in a multinational oil company. South African Journal of Industrial Psychology, 33, 49-56.

Ones, D. S., Viswesvaran, C., \& Reiss, A. D. (1996). Role of social desirability in personality testing for personnel selection: The red herring. Journal of Applied Psychology, 81, 660679.

Organ, D. W. (1988). Organizational citizenship behavior: The good soldier syndrome. Lexington, MA: Lexington Books. 
Organ, D. W., \& Ryan, M. (1995). A meta-analytic review of attitudinal and dispositional predictors of organizational citizenship behavior. Personnel Psychology, 48, 775-802.

Overton, R. (1998). A comparison of fixed-effects and mixed(random-effects) models for metaanalysis tests of moderator variable effects. Psychological Methods, 3, 354-379.

*Parker, S. L., Jimmieson, N. L., \& Amiot, C. E. (2010). Self-determination as a moderator of demands and control: Implications for employee strain engagement. Journal of Vocational Behavior, 76, 52-67.

Parker, S. K., Williams, H. M., \& Turner, N. (2006). Modeling the antecedents of proactive behavior at work. Journal of Applied Psychology, 91, 636-652.

*Perron, B. E., \& Hiltz, B. S. (2006). Burnout and secondary trauma among forensic interviewers of abused children. Child \& Adolescent Social Work Journal, 23, 216-234.

Piccolo, R. F., \& Colquitt, J. A. (2006). Transformational leadership and job behaviors: The mediating role of core job characteristics. Academy of Management Journal, 49, 327-340.

Podsakoff, N. P., Whiting, S.W., Podsakoff, P.M., \& Blume, B.D. (2009). Individual- and organizational-level consequences of organizational citizenship behaviors: A metaanalysis. Journal of Applied Psychology, 94, 122-141.

Podsakoff, P. M., MacKenzie, S. B., Bommer, W. H. (1996). Transformational leader behaviors and substitutes for leadership as determinants of employee satisfaction, commitment, trust, and organizational citizenship behaviors. Journal of Management, 22, 259-298.

Podsakoff, P. M., MacKenzie, S. B., Lee, J.-Y., \& Podsakoff, N. P. (2003). Common method biases in behavioral research: A critical review of the literature and recommended remedies. Journal of Applied Psychology, 88, 879-903. 
Podsakoff, P. M., MacKenzie, S. B., Moorman, R. H., \& Fetter, R. (1990). Transformational leader behaviors and their effects on followers trust in leader satisfaction and organizational citizenship behaviors. Leadership Quarterly, 1, 107-142.

Podsakoff, P. M., MacKenzie, S. B., Paine, J. B., \& Bachrach, D. G. (2000). Organizational citizenship behaviors: A critical review of the theoretical and empirical literature and suggestions for future research. Journal of Management, 26, 513-563.

Purvanova, R. K., Bono, J. E., \& Dzieweczynski, J. (2006). Transformational leadership, job characteristics, and organizational citizenship performance. Human Performance, 19, 122.

Raju, N., Burke, M., Normand, J., \& Langlois, G. (1991). A new meta-analytic approach. Journal of Applied Psychology, 76, 432-446.

*Rich, B. L. (2006). Job engagement: Construct validation and relationships with job satisfaction, job involvement, and intrinsic motivation. Unpublished doctoral dissertation, University of Florida, Gainesville, FL.

*Rich, B. L., LePine, J. A., \& Crawford, E. R. (2010). Job engagement: Antecedents and effects on job performance. Academy of Management Journal. in press.

*Richardsen, A. M., Burke, R. J., \& Martinussen, M. (2006). Work and health outcomes among police officers: The mediating role of police cynicism and engagement. International Journal of Stress Management, 13, 555-574.

Riketta, M. (2002). Attitudinal organizational commitment and job performance: A metaanalysis. Journal of Organizational Behavior, 23, 257-266.

Rosenthal, R. (1979). The "file drawer problem" and tolerance for null results. Psychological Bulletin, 86, 638-641. 
Rothbard, N. P. (2001). Enriching or depleting? The dynamics of engagement in work and family roles. Administrative Science Quarterly, 46, 655-684.

*Rothmann, S. (2008). Job satisfaction, occupational stress, burnout and work engagement as components of work-related wellbeing. South African Journal of Industrial Psychology, $34,11-16$.

*Rothmann, S., \& Pieterse, J. (2007). Predictors of work-related well-being in sector education training authorities. South African Journal of Economic and Management Sciences, 10, 298-312.

Ryan, R. M., \& Deci, E. L. (2001). On happiness and human potentials: A review of research on hedonic and eudaimonic well-being. Annual Review of Psychology, 52, 141-166.

Sackett, P., Harris, M., \& Orr, J. (1986). On seeking moderator variables in the meta-analysis of correlational data: A Monte Carlo investigation of statistical power and resistance ot type I error. Journal of Applied Psychology, 71, 302-310.

Salgado, J. F. (2003). Predicting job performance using FFM and non-FFM personality measures. Journal of Occupational and Organizational Psychology, 76, 323-346.

Saltz, J. L. (2004). Beyond simple similarity: The relationship of leader-follower personality fit with follower satisfaction with the leader and follower commitment to the organization. Unpublished doctoral dissertation, University of Maryland, College Park, MD.

*Saks, A. M. (2006). Antecedents and consequences of employee engagement. Journal of Managerial Psychology, 21, 600-619.

*Salanova, M. \& Schaufeli, W. B. (2008). A cross-national study of work engagement as a mediator between job resources and proactive behaviour. The International Journal of Human Resource Management, 19, 116-131. 
Salanova, M., Agut, S., \& Peiro, J. (2005). Linking organizational resources and work engagement to employee performance and customer loyalty: The mediation of service climate. Journal of Applied Psychology, 90, 1217-1227.

*Schaufeli, W. B., \& Baker, A. B. (2004). Job demands, job resources, and their relationship with burnout and engagement: A multi-sample study. Journal of Organizational Behavior, 25, 293-315.

*Schaufeli, W. B., Bakker, A. B., Van Rhenen, W. (2009). How changes in job demands and resources predict burnout, work engagement, and sickness absenteeism. Journal of Organizational Behavior, 30, 893-917.

Schaufeli, W. B., \& Salanova, M. (2007). Work engagement: An emerging psychological concept and its implications for organizations. In S. Gilliland, D. Steiner \& D. Skarlicki (Eds.), Research in social issues in management (Vol. 5, pp. 135-177). Grenwich, CT: Information Age Publishers.

Schaufeli, W. B., Salanova, M., Gonzalez-Roma, V., \& Bakker, A. B. (2002). The measurement of engagement and burnout: A two sample confirmatory factor analytic approach. Journal of Happiness Studies, 3, 71-92.

*Schaufeli, W. B., Taris, T. W., \& van Rhenen, W. (2008). Workaholism, burnout, and engagement: Three of a kind or three different kinds of employee well-being? Applied Psychology: An International Review, 57,173-203.

Schmidt, F. L., Viswesvaran, C., \& Ones, D. S. (2000). Reliability is not validity and validity is not reliability. Personnel Psychology, 53, 901-912. 
*Shimazu, et al. (2008). Work engagement in Japan: Validation of the Japanese version of the Utrecht Work Engagement scale. Applied Psychology: An International Review, 57, 510523.

*Shin, K. H. (2003). Job engagement and job burnout in a South Korean sample. Unpublished doctoral dissertation: Kansas State University, Manhattan, Kansas.

*Shirom, A., Toker, S., Berliner, S., Shapira, I., \& Melamed, S. (2006). Work-related vigor and job satisfaction relationships with inflammation biomarkers among employed adults. Dimensions of well-being: Research and interventions, 254-274.

*Shirom. A., \& Armon, G. (2010). The across-time effects of the five-factor model of personality on vigor and its facets. Unpublished manuscript.

*Shraga, O., \& Shirom, A. Vigor and Job Satisfaction Relationships. Unpublished manuscript. Simmering, M. J., Colquitt, J. A., Noe, R. A., \& Porter, C. O. L. H. (2003). Conscientiousness, autonomy fit, and employee development: A longitudinal field study. Journal of Applied Psychology, 88, 954-963.

*Simpson, M. R. (2009). Predictors of work engagement among medical-surgical registered nurses. Western Journal of Nursing Research, 31, 44-65.

*Sonnentag, S. (2003). Recovery, work engagement, and proactive behavior: A new look at the interface between nonwork and work. Journal of Applied Psychology, 88, 518-528.

Spector, P. E., \& Jex, S. M. (1991). Relations of job characteristics from multiple data sources with employee affect, absence, turnover intentions, and health. Joumal ofApplied Psychology, 76, 46-53. 
*Tai, W-T., Liu, S-C. (2007). An investigation of the influences of job autonomy and neuroticism on job stressor-strain relations. Social Behavior \& Personality: An International Journal, 35, 1007-1019.

Thoresen, C. J., Kaplan, S. A., Barsky, A. P., Warren, C. R., \& de Chermont, K. (2003). The affective underpinnings of job perceptions and attitudes: A meta-analytic review and integration. Psychological Bulletin, 129, 914-945.

*Timms, C., Graham, D., \& Cottrell, D. (2007). "I just want to teach" Queensland independent school teachers and their workload. Journal of Educational Administration, 5, 569-586.

Van den Berg, P. T., \& Feij, J. A. (2003). Complex relationships among personality traits, job characteristics, and work behaviors. International Journal of Selection and Assessment, 11, 326-339.

*Van den Broeck, A., Vansteenkiste, M., De Witte, H., \& Lens, W. (2008). Explaining the relationships between job characteristics, burnout, and engagement: The role of basic psychological need satisfaction. Work \& Stress, 22, 277-294.

Van Dyne, L., Cummings, L., \& Parks, J. (1995). Extra-role behaviors: In pursuit of construct and definitional clarity (a bridge over muddied waters). In L. Cummings \& B. Staw (Eds.), Research in organizational behavior (Vol. 17, pp. 215-215). Greenwich, CT: JAI Press.

*van Emmerick, I. J. H., \& Euwema, M. C., \& Bakker, A. B. (2007). Threats of workplace violence and the buffering effect of social support. Group \& Organization Management, $32,152-175$.

*Vansteenkiste, M., Neyrinck, B., Niemiec, C. P., Soenens, B., De Witte, H., Van Den Broeck, A. (2007). On the relations among work value orientations, psychological need 
satisfaction and job outcomes: A self-determination theory approach. Journal of Occupational \& Organizational Psychology, 80, 251-277.

Viswesvaran, C., \& Ones, D. (1995). Theory testing: Combining psychometric meta-analysis and structural equations modeling. Personnel Psychology, 48, 865-885.

Watson, D., \& Clark, L. (1997). Extraversion and its positive emotional core. In R. Hogan, J. Johnson \& S. Briggs (Eds.), Handbook of personality psychology (pp. 767-793). San Diego, CA: Academic Press.

Watson, D., Clark, L., \& Tellegen, A. (1988). Development and validation of brief measures of positive and negative affect: the PANAS scales. Journal of Personality and Social Psychology, 54, 1063-1070.

*Wefald, A. (2008). An examination of job engagement, transformational leadership, and related psychological constructs. Unpublished doctoral dissertation, Kansas State University, Manhattan, Kansas.

Weiss, H. M. (2002). Deconstructing job satisfaction: Separating evaluations, beliefs, and affective experiences. Human Resource Management Review, 12, 173-194.

Whittington, J. L., Goodwin, V. L., \& Murray, B. (2004). Transformational leadership, goal difficulty, and job design: Independent and interactive effects on employee outcomes. The Leadership Quarterly, 15, 593-606.

*Wiese, B. S., \& Salmela-Aro, K. (2008). Goal conflict and facilitation as predictors of workfamily satisfaction and engagement. Journal of Vocational Behavior, 73, 490-497.

*Wildermuth, C. (2008). Engaged to serve: The relationship between employee engagement and the personality of human services professionals and paraprofessionals. Unpublished doctoral dissertation, Bowling Green State University, Bowling Green, $\mathrm{OH}$. 
*Xanthopoulou, D. Bakker, A. B., Demerouti, E., \& Schaufeli, W. B. (2009). Work engagement and financial returns: A diary study on the role of job and personal resources. Journal of Occupational and Organizational Psychology, 82, 183-200.

*Xanthopoulou, D., Bakker, A. B., Demerouti, E., \& Schaufeli, W. B. (2007). The role of personal resources in the job demands-resources model. International Journal of Stress Management, 14, 121-141.

*Xanthopoulou, D., Bakker, A. B., Heuven, E., Demerouti, E., \& Schaufeli, W. B. (2008). Working in the sky: A diary study on work engagement among flight attendants. Journal of Occupational Health Psychology, 13, 345-356.

*Zhang, Y., Gan, Y., \& Cham, H. (2007). Perfectionism, academic burnout and engagement among Chinese college students: A structural equation model analysis. Personality and Individual Differences, 43, 1529-1540. 
Footnotes

${ }^{1 .}$ We included the disengagement subscale of the Oldenburg Burnout Inventory (OLBI; Demerouti, 1999) as measure of engagement for three reasons. First, the scale refers to the performance of the work itself, in terms of identification with and emotions towards the task (Demerouti, Bakker, Vardakou, \& Kantas, 2003). Second, the items for disengagement are written to reflect both ends of the engagement continuum rather than only disengagement (Demerouti et al., 2003), consistent with many other measures of work engagement (e.g., May et al., 2004). Third, burnout is widely recognized as a construct consisting of the three dimensions of exhaustion, cynicism, and reduced efficacy, which are not reflected in the OLBI disengagement subscale.

2.We also performed a meta-analysis to test the strength of the relations between the factors of engagement in order to justify our conceptualization as a higher-order construct. As expected, the three components were strongly correlated, as expected. The correlation between physical and emotional was $M \rho=.82$, between physical and cognitive was $M \rho=.81$, and between emotional and cognitive was $M \rho=$ .76. For a full description of the results of these analyses, readers can write to the first author.

3. There are several other recognized job characteristics that are conceptually linked with work engagement, according to job characteristics models (see Humphrey et al., 2007). However, we focus on those job characteristics that have been examined in the engagement literature. 


\section{Work Engagement 58}

\section{Figure Captions}

Figure 1. Conceptual Framework.

Figure 2. Maximum likelihood parameter estimates for the hypothesized model. Statistics are standardized path coefficients. Dashed paths are not significant; otherwise, all paths are significant at $p<$ .01. $\mathrm{N}_{\mathrm{h}}=1091$. 


\section{Dispositional Characteristics}

- Proactive Personality

- Conscientiousness

- Positive Affect

Figure 1.

Work Engagement

Job Attitudes

- Job Satisfaction

- Organizational Commitment

- Job Involvement

\section{$\rightarrow$ WORK BEHAVIOR}

Job Performance

- Task Performance

- Contextual Performance

Leadership

- Transformational

- Leader-Member Exchange

\section{- Positive Affect}

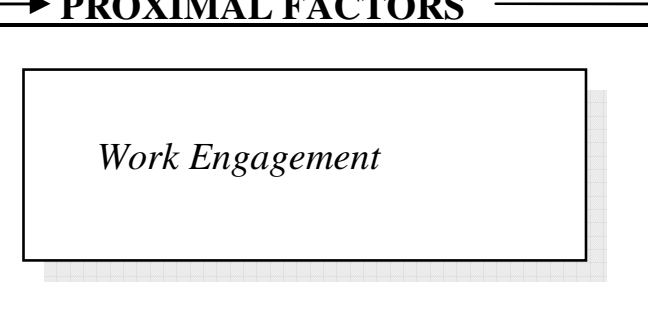

- Task Significance

• Contextual Performance 


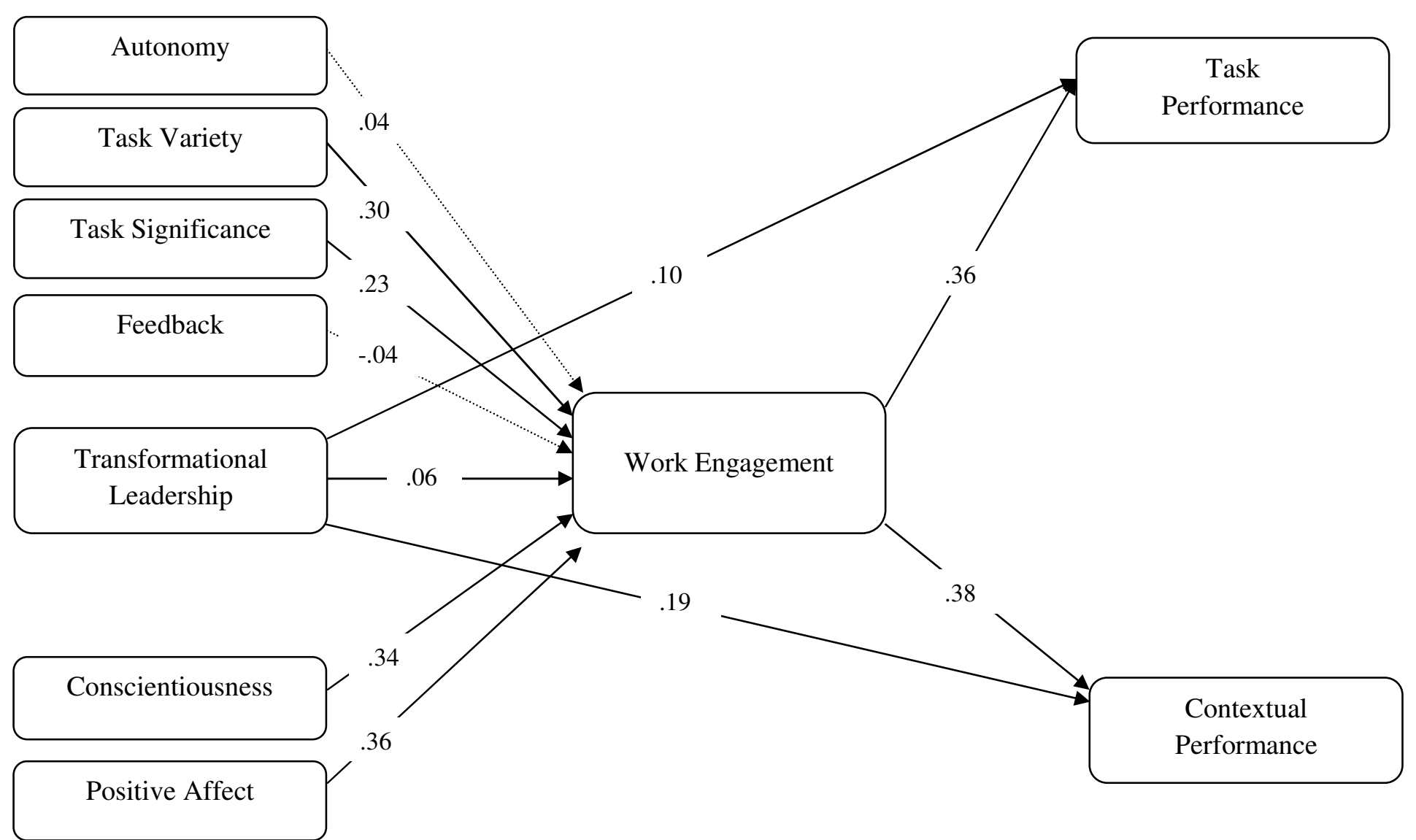

Figure 2. 
Table 1

Measure Descriptions

\begin{tabular}{|c|c|c|c|c|c|}
\hline Measure & Original Source (s) & Description of Measure & Key Components of Definition & Sample Items & $k$ \\
\hline $\begin{array}{l}\text { Utrecht Work } \\
\text { Engagement Scale } \\
\text { (UWES) }\end{array}$ & $\begin{array}{l}\text { Schaufeli, } \\
\text { Salanova, } \\
\text { Gonzalez-Roma, \& } \\
\text { Bakker (2002) }\end{array}$ & - $9-17$ items & $\begin{array}{l}\text { - positive, fulfilling, work-related state of mind } \\
\text { - persistent and pervasive affective-cognitive state } \\
\text { - energy and mental resilience while working } \\
\text { - significance, enthusiasm, inspiration, pride, and challenge } \\
\text { - fully concentrated and engrossed in one's work, time passes } \\
\text { quickly and one has difficulties with detaching from work }\end{array}$ & $\begin{array}{l}\text { - "Time flies when I am working" } \\
\text { - "I am proud of the work that I do." } \\
\text { - "At my job I feel strong and vigorous" }\end{array}$ & 73 \\
\hline $\begin{array}{l}\text { Disengagement } \\
\text { (Subscale of OLBI) }\end{array}$ & $\begin{array}{l}\text { Demerouti, } \\
\text { Bakker, Vardakou, } \\
\& \text { Kantas (2003) }\end{array}$ & $\begin{array}{l}\text { - Measures vary in } \\
\text { length, commonly } 8 \\
\text { items. }\end{array}$ & $\begin{array}{l}\text { - emotions toward the work task } \\
\text { relationship between employees and their job, particularly with } \\
\text { respect to their engagement, identification, and willingness to } \\
\text { continue the same occupation }\end{array}$ & $\begin{array}{l}\text { - "I get more and more engaged in my work." } \\
\text { - "I find my work to be a positive challenge." } \\
\text { - "I always find new and interesting aspects in my work." }\end{array}$ & 6 \\
\hline $\begin{array}{l}\text { Shirom-Melamed } \\
\text { Vigor Measure } \\
\text { (SMVM) }\end{array}$ & Shirom, (2004) & - 14 items & $\begin{array}{l}\text { - affective response in the context of work organizations } \\
\text { - feelings of physical strength, emotional energy, and cognitive } \\
\text { liveliveness. }\end{array}$ & $\begin{array}{l}\text { - "I feel energetic." } \\
\text { • "I feel like I can think rapidly." } \\
\text { - "I feel able to show warmth to others."" }\end{array}$ & 4 \\
\hline $\begin{array}{l}\text { Psychological } \\
\text { Engagement }\end{array}$ & $\begin{array}{l}\text { May, Gilson, \& } \\
\text { Harter (2004) }\end{array}$ & $\begin{array}{l}\text { - } 13 \text { items based on } \\
\text { Kahn (1990) }\end{array}$ & $\begin{array}{l}\text { - harnessing of members' selves to their work roles } \\
\text { - employ and express themselves physically, cognitively, and } \\
\text { emotionally during role performances }\end{array}$ & $\begin{array}{l}\text { - "Performing my job is so absorbing that I forget about } \\
\text { everything else." } \\
\text { - "I often feel emotionally detached from my job." } \\
\text { - "I exert a lot of energy performing my job." }\end{array}$ & 3 \\
\hline Job Engagement & $\begin{array}{l}\text { Rich, LePine, \& } \\
\text { Crawford (2010) }\end{array}$ & $\begin{array}{l}\text { - } 18 \text { items based on } \\
\text { Kahn (1990) }\end{array}$ & $\begin{array}{l}\text { - simultaneous investment of cognitive, affective, and physical } \\
\text { energies into role performance }\end{array}$ & $\begin{array}{l}\text { - "I exert a lot of energy on my job" } \\
\text { - "I am enthusiastic about my job" } \\
\text { - "At work I am absorbed by my job" }\end{array}$ & 3 \\
\hline Job Engagement & Saks (2006) & $\begin{array}{l}\text { - } 6 \text { items based on Kahn } \\
\text { (1990) }\end{array}$ & $\begin{array}{l}\text { - extent to which an individual is psychologically present in a } \\
\text { particular organizational role } \\
\text { - all consuming }\end{array}$ & $\begin{array}{l}\text { - "I really 'throw' myself into my job." } \\
\text { - "Sometimes I am so into my job that I lose track of } \\
\text { time." } \\
\text { - "This job is all consuming; I am totally into it." }\end{array}$ & 1 \\
\hline
\end{tabular}


Table 2

Mean Sample-Based Reliability Estimates used for Analyses

\begin{tabular}{|c|c|c|c|}
\hline$\frac{\text { Category }}{\text { Construct }}$ & $k$ & $\mathrm{~N}$ & Mean Reliability Estimate \\
\hline Work Engagement & 90 & 63,813 & .88 \\
\hline \multicolumn{4}{|l|}{ Job Attitudes } \\
\hline Job Satisfaction & 21 & 11,214 & .85 \\
\hline Organizational Commitment & 15 & 11,449 & .80 \\
\hline Job Involvement & 8 & 2,095 & .85 \\
\hline \multicolumn{4}{|l|}{ Job Characteristics } \\
\hline$\overline{\text { Autonomy }}$ & 41 & 25,730 & .81 \\
\hline Task Variety & 8 & 9,107 & .79 \\
\hline Task Significance & 6 & 7,660 & .83 \\
\hline Problem Solving & 9 & 10,122 & .78 \\
\hline Job Complexity & 5 & 3,531 & .69 \\
\hline Feedback & 10 & 10,155 & .80 \\
\hline Social Support & 47 & 22,324 & .83 \\
\hline Physical Demands & 2 & 2,974 & .81 \\
\hline Work Conditions & 9 & 6,565 & .80 \\
\hline \multicolumn{4}{|l|}{ Leadership } \\
\hline Transformational & 6 & 3,148 & .87 \\
\hline Leader-member exchange & 3 & 2,466 & .90 \\
\hline \multicolumn{4}{|l|}{ Dispositional Characteristics } \\
\hline Conscientiousness & 15 & 8,233 & .82 \\
\hline Positive Affect & 13 & 6,578 & .77 \\
\hline Proactive Personality & 6 & 4,304 & .77 \\
\hline \multicolumn{4}{|l|}{ Job Performance $^{\mathrm{a}}$} \\
\hline Task Performance (self-rated) & 10 & 3,951 & .83 \\
\hline Task Performance (other-rated) ${ }^{\mathrm{a}}$ & 6 & 819 & .59 \\
\hline Contextual Performance (self-rated) & 6 & 2,740 & .77 \\
\hline Contextual Performance (other-rated) ${ }^{\mathrm{a}}$ & 5 & 642 & .51 \\
\hline
\end{tabular}

Note. ${ }^{\text {a }}$ For other-rated performance, corrections were made using inter-rater reliability. Because no studies were available in our dataset providing these estimates, the values for other-rated task and contextual performance were taken from Christian et al. (2010). 
Table 3

Results for Meta-Analysis of Work Engagement with Job Attitudes

\begin{tabular}{|c|c|c|c|c|c|c|c|c|c|c|c|c|}
\hline \multirow{2}{*}{$\frac{\text { Category }}{\text { Construct }}$} & \multirow[b]{2}{*}{$k$} & \multirow[b]{2}{*}{$\mathrm{N}$} & \multirow[b]{2}{*}{$M_{\mathrm{r}}$} & \multirow[b]{2}{*}{$S D_{\mathrm{r}}$} & \multirow[b]{2}{*}{$M_{\rho}$} & \multicolumn{4}{|c|}{$\begin{array}{l}95 \% \text { Conf. } \\
\text { Int }\end{array}$} & \multicolumn{2}{|c|}{$\begin{array}{l}80 \% \text { Cred. } \\
\text { Int. }\end{array}$} & \multirow{2}{*}{$\begin{array}{c}\% \text { Due to } \\
\text { artifacts }\end{array}$} \\
\hline & & & & & & $\mathrm{SE}_{M \rho}$ & $\mathrm{L}$ & $\mathrm{U}$ & $\mathrm{SD}$ & $\mathrm{L}$ & $\mathrm{U}$ & \\
\hline \multicolumn{13}{|l|}{ Job Attitudes } \\
\hline Job Satisfaction & 20 & 9,725 & .46 & .19 & .53 & .04 & .44 & .61 & .19 & .29 & .76 & 3.70 \\
\hline Organizational Commitment & 14 & 7,569 & .47 & .10 & .59 & .03 & .53 & .64 & .11 & .46 & .71 & 12.47 \\
\hline Job Involvement & 5 & 1,175 & .45 & .06 & .52 & .04 & .45 & .59 & .08 & .44 & .59 & 51.42 \\
\hline
\end{tabular}

Note. $k=$ the number of independent effect sizes included in each analysis; $\mathrm{N}=$ sample size. $M \mathrm{r}=$ mean uncorrected correlation; $S D \mathrm{r}=$ standard deviation of uncorrected correlations; $\mathrm{M}_{\rho}=$ mean corrected correlation (corrected for unreliability in the predictor and criterion); $\mathrm{SE}_{M_{\rho}}=$ standard error of $M_{\rho} ; 95 \%$ Conf. Int. $=95 \%$ Confidence Interval for $M_{\rho} ; \mathrm{SD}_{\rho}=$ standard deviation of estimated $\rho$ 's; $80 \%$ Cred. Int. $=80 \%$ Credibility Interval. 
Table 4

Results for Meta-Analysis of Antecedents and Consequences of Work Engagement

\begin{tabular}{|c|c|c|c|c|c|c|c|c|c|c|c|c|}
\hline \multirow{2}{*}{$\frac{\frac{\text { Category }}{\text { Construct }}}{}$} & \multirow[b]{2}{*}{$k$} & \multirow[b]{2}{*}{$\mathrm{N}$} & \multirow[b]{2}{*}{$M_{\mathrm{r}}$} & \multirow[b]{2}{*}{$S D_{\mathrm{r}}$} & \multirow[b]{2}{*}{$M_{\rho}$} & \multicolumn{4}{|c|}{$\begin{array}{l}95 \% \text { Conf. } \\
\text { Int. }\end{array}$} & \multicolumn{2}{|c|}{$\begin{array}{c}80 \% \text { Cred. } \\
\text { Int. }\end{array}$} & \multirow{2}{*}{$\begin{array}{l}\% \text { Due to } \\
\text { artifacts }\end{array}$} \\
\hline & & & & & & $\mathrm{SE}_{M \rho}$ & $\mathrm{L}$ & $\mathrm{U}$ & $\mathrm{SD}_{\rho}$ & $\mathrm{L}$ & $\mathrm{U}$ & \\
\hline \multicolumn{13}{|l|}{ Job Characteristics } \\
\hline Autonomy & 43 & 24,499 & .33 & .10 & .39 & .02 & .36 & .43 & .11 & .26 & .53 & 15.18 \\
\hline Task Variety & 9 & 9,211 & .44 & .05 & .53 & .02 & .49 & .57 & .06 & .46 & .60 & 22.51 \\
\hline Task Significance & 4 & 5,870 & .42 & .06 & .51 & .03 & .44 & .57 & .06 & .43 & .58 & 12.47 \\
\hline Feedback & 10 & 7,179 & .27 & .07 & .33 & .02 & .28 & .38 & .08 & .24 & .41 & 26.52 \\
\hline Problem Solving & 9 & 9,578 & .23 & .08 & .28 & .03 & .22 & .33 & .09 & .17 & .38 & 16.17 \\
\hline Job Complexity & 6 & 1,662 & .19 & .02 & .24 & .03 & .18 & .30 & .06 & .21 & .27 & 100.00 \\
\hline Social Support & 38 & 18,226 & .27 & .08 & .32 & .02 & .29 & .35 & .10 & .22 & .43 & 26.44 \\
\hline Physical Demands & 2 & 2,333 & -.19 & - & -.23 & .00 & -.24 & -.22 & .01 & - & - & 100.00 \\
\hline Work Conditions & 9 & 5,488 & -.18 & .03 & -.22 & .02 & -.26 & -.18 & .06 & -.26 & -.17 & 63.78 \\
\hline \multicolumn{13}{|l|}{ Leadership } \\
\hline Transformational & 4 & 777 & .24 & .05 & .27 & .05 & .18 & .36 & .06 & .21 & .33 & 100.00 \\
\hline Leader-Member Exchange & 4 & 4,695 & .28 & .02 & .31 & .02 & .28 & .35 & .02 & .28 & .34 & 100.00 \\
\hline \multicolumn{13}{|l|}{ Dispositional Characteristics } \\
\hline Conscientiousness & 12 & 5,821 & .36 & .08 & .42 & .03 & .37 & .47 & .09 & .32 & .52 & 25.94 \\
\hline Positive Affect & 14 & 6,715 & .37 & .16 & .43 & .04 & .35 & .52 & .16 & .23 & .64 & 7.19 \\
\hline Proactive Personality & 6 & 4,304 & .35 & .07 & .44 & .03 & .37 & .51 & .08 & .34 & .53 & 22.35 \\
\hline \multicolumn{13}{|l|}{ Job Performance } \\
\hline Task Performance & 14 & 4,562 & .36 & .10 & .43 & .03 & .37 & .49 & .11 & .30 & .55 & 27.78 \\
\hline Contextual Performance & 10 & 3,654 & .26 & .08 & .34 & .03 & .28 & .40 & .10 & .23 & .45 & 35.19 \\
\hline
\end{tabular}

Note. $k=$ the number of independent effect sizes included in each analysis; $\mathrm{N}=$ sample size. $M \mathrm{r}=$ mean uncorrected correlation; $S D \mathrm{r}=$ standard deviation of uncorrected correlations; $\mathrm{M}_{\rho}=$ mean corrected correlation (corrected for unreliability in the predictor and criterion); $\mathrm{SE}_{M_{\rho}}=$ standard error of $M_{\rho} ; 95 \%$ Conf. Int. $=95 \%$ Confidence Interval for $M_{\rho} ; \mathrm{SD}_{\rho}=$ standard deviation of estimated $\rho$ 's; $80 \%$ Cred. Int. $=80 \%$ Credibility Interval. 
Table 5

Results for Moderator Analyses by Engagement Measure Type

\begin{tabular}{|c|c|c|c|c|c|c|c|c|c|c|c|c|}
\hline Category & \multirow[b]{2}{*}{$k$} & \multirow[b]{2}{*}{$\mathrm{N}$} & \multirow[b]{2}{*}{$M_{\mathrm{r}}$} & \multirow[b]{2}{*}{$S D_{\mathrm{r}}$} & \multirow[b]{2}{*}{$M_{\rho}$} & \multirow[b]{2}{*}{$\mathrm{SE}_{M \rho}$} & \multicolumn{2}{|c|}{$\begin{array}{l}\text { 95\% Conf. } \\
\text { Int. }\end{array}$} & \multirow[b]{2}{*}{$\mathrm{SD}_{\rho}$} & \multicolumn{2}{|c|}{$\begin{array}{l}80 \% \text { Cred. } \\
\text { Int. }\end{array}$} & \multirow{2}{*}{$\begin{array}{c}\% \text { Due to } \\
\text { artifacts }\end{array}$} \\
\hline Construct Measure Type & & & & & & & $\mathrm{L}$ & $\mathrm{U}$ & & $\mathrm{L}$ & $\mathrm{U}$ & \\
\hline \multicolumn{13}{|l|}{ Job Attitudes } \\
\hline \multicolumn{13}{|l|}{ Job Satisfaction } \\
\hline UWES & 13 & 6,654 & .46 & .22 & .52 & .06 & .40 & .64 & .22 & .24 & .80 & 2.42 \\
\hline Other measures & 8 & 3,453 & .49 & .10 & .55 & .04 & .48 & .62 & .10 & .42 & 67 & 14.48 \\
\hline \multicolumn{13}{|l|}{ Organizational Commitment } \\
\hline UWES & 13 & 7,467 & .47 & .10 & .59 & .03 & .53 & .65 & .10 & .46 & .72 & 11.97 \\
\hline Other measures & 2 & 484 & .41 & .09 & .48 & .07 & .33 & .62 & .10 & .36 & .59 & 28.90 \\
\hline \multicolumn{13}{|l|}{ Job Involvement } \\
\hline UWES & 4 & 930 & .46 & .08 & .52 & .05 & .42 & .62 & .10 & .42 & .63 & 34.16 \\
\hline Other measures & 2 & 627 & .47 & - & .53 & .02 & .48 & .58 & .04 & - & - & 100.00 \\
\hline \multicolumn{13}{|l|}{ Job Characteristics } \\
\hline \multicolumn{13}{|l|}{ Autonomy } \\
\hline UWES & 38 & 20,247 & .33 & .11 & .39 & .02 & .36 & .43 & .12 & .25 & .54 & 14.54 \\
\hline Other measures & 5 & 3,800 & .38 & .06 & .43 & .03 & .36 & .49 & .07 & .35 & .51 & 26.60 \\
\hline \multicolumn{13}{|l|}{ Feedback } \\
\hline UWES & 8 & 4,130 & .28 & .06 & .36 & .03 & .30 & .41 & .08 & .28 & .44 & 37.63 \\
\hline Other measures & 2 & 3,049 & .26 & .05 & .29 & .04 & .21 & .37 & .06 & .22 & .35 & 18.81 \\
\hline \multicolumn{13}{|l|}{ Social Support } \\
\hline UWES & 32 & 17,258 & .27 & .08 & .32 & .02 & .29 & .35 & .09 & .21 & .42 & 25.04 \\
\hline Other measures & 8 & 1,643 & .32 & .10 & .38 & .04 & .29 & .46 & .12 & .24 & .51 & 33.07 \\
\hline \multicolumn{13}{|l|}{ Dispositional Characteristics } \\
\hline \multicolumn{13}{|l|}{ Conscientiousness } \\
\hline UWES & 9 & 4,167 & .34 & .05 & .41 & .02 & .36 & .45 & .07 & .35 & .47 & 51.33 \\
\hline Other measures & 4 & 2,036 & .38 & .11 & .44 & .06 & .33 & .56 & .12 & .30 & .58 & 13.41 \\
\hline \multicolumn{13}{|l|}{ Positive Affect } \\
\hline UWES & 8 & 3,897 & .44 & .17 & .52 & .06 & .40 & .63 & .17 & .30 & .73 & 5.39 \\
\hline Other measures & 7 & 3,200 & .31 & .11 & .36 & .04 & .28 & .45 & .12 & .22 & .50 & 15.35 \\
\hline \multicolumn{13}{|l|}{ Job Performance } \\
\hline \multicolumn{13}{|l|}{ Task Performance } \\
\hline UWES & 9 & 3,755 & .39 & .07 & .45 & .03 & .40 & .51 & .09 & .36 & .55 & 30.71 \\
\hline Other measures & 5 & 807 & .23 & .10 & .30 & .06 & .19 & .42 & .13 & .18 & .43 & 50.06 \\
\hline \multicolumn{13}{|l|}{ Contextual Performance } \\
\hline UWES & 6 & 3,029 & .24 & .06 & .31 & .03 & .25 & .37 & .08 & .23 & .39 & 43.83 \\
\hline Other measures & 4 & 625 & .36 & .03 & .48 & .05 & .39 & .58 & .09 & .44 & .52 & 100.00 \\
\hline
\end{tabular}

Note. $k=$ the number of independent effect sizes included in each analysis; $\mathrm{N}=$ sample size. $M \mathrm{r}=$ mean uncorrected correlation; $S D \mathrm{r}=$ standard deviation of uncorrected correlations; $\mathrm{M}_{\rho}=$ mean corrected correlation (corrected for unreliability in the predictor and criterion); $\mathrm{SE}_{M_{\rho}}=$ standard error of $M_{\rho} ; 95 \%$ Conf. Int. $=95 \%$ Confidence Interval for $M_{\mathrm{p}} ; \mathrm{SD}_{\rho}=$ standard deviation of estimated $\rho$ 's; $80 \%$ Cred. Int. $=80 \%$ Credibility Interval. 
Table 6

Moderator Analyses by Study Design

\begin{tabular}{|c|c|c|c|c|c|c|c|c|c|c|c|c|c|}
\hline \multicolumn{2}{|l|}{ Category } & \multirow[b]{2}{*}{$k$} & \multirow[b]{2}{*}{$\mathrm{N}$} & \multirow[b]{2}{*}{$M_{\mathrm{r}}$} & \multirow[b]{2}{*}{$S D_{\mathrm{r}}$} & \multirow[b]{2}{*}{$M_{\rho}$} & \multicolumn{4}{|c|}{$\begin{array}{l}95 \% \text { Conf. } \\
\text { Int. }\end{array}$} & \multicolumn{2}{|c|}{$\begin{array}{c}80 \% \text { Cred. } \\
\text { Int. }\end{array}$} & \multirow{2}{*}{$\begin{array}{l}\% \text { Due to } \\
\text { artifacts }\end{array}$} \\
\hline Construct & Study Design & & & & & & $\mathrm{SE}_{M \rho}$ & $\mathrm{L}$ & $\mathrm{U}$ & $\mathrm{SD}_{\rho}$ & $\mathrm{L}$ & $\mathrm{U}$ & \\
\hline \multicolumn{14}{|c|}{ Job Characteristics } \\
\hline \multicolumn{14}{|c|}{ Autonomy } \\
\hline & Concurrent & 34 & 20,536 & .34 & .09 & .41 & .02 & .37 & .44 & .10 & .29 & .52 & 18.48 \\
\hline & Lagged & 6 & 3,020 & .29 & .16 & .33 & .06 & .20 & .46 & .16 & .13 & .53 & 9.15 \\
\hline & Within-person & 3 & 243 & .35 & .15 & .41 & .10 & .20 & .61 & .18 & .21 & .60 & 30.05 \\
\hline \multicolumn{14}{|c|}{ Social Support } \\
\hline & Concurrent & 34 & 16,306 & .27 & .07 & .32 & .02 & .29 & .35 & .09 & .23 & .42 & 30.60 \\
\hline & Lagged & 3 & 1,866 & .25 & .13 & .29 & .08 & .14 & .45 & .13 & .13 & .46 & 10.91 \\
\hline & Within-person & 2 & 98 & .40 & .14 & .51 & .14 & .23 & .79 & .05 & .33 & .69 & 100.00 \\
\hline \multicolumn{14}{|c|}{ Job Performance } \\
\hline \multicolumn{14}{|c|}{ Task Performance } \\
\hline & Concurrent & 9 & 3,557 & .39 & .07 & .45 & .03 & .39 & .51 & .09 & .35 & .54 & 35.13 \\
\hline & Lagged & 3 & 881 & .26 & .08 & .31 & .06 & .20 & .43 & .10 & .22 & .41 & 43.81 \\
\hline & Within-person & 4 & 213 & .45 & .08 & .57 & .08 & .42 & .71 & .15 & .46 & .67 & 71.00 \\
\hline \multicolumn{14}{|c|}{ Contextual Performance } \\
\hline & Concurrent & 8 & 3,061 & .25 & .08 & .32 & .04 & .25 & .39 & .10 & .21 & .43 & 33.75 \\
\hline & Lagged & 3 & 637 & .30 & .07 & .44 & .06 & .32 & .57 & .03 & .35 & .54 & 100.00 \\
\hline & Within-person & 1 & 44 & .39 & - & - & - & - & - & - & - & - & - \\
\hline
\end{tabular}

Note. $k=$ the number of independent effect sizes included in each analysis; $\mathrm{N}=$ sample size. $M \mathrm{r}=$ mean uncorrected correlation; $S D r=$ standard deviation of uncorrected correlations; $\mathrm{M}_{\rho}=$ mean corrected correlation (corrected for unreliability in the predictor and criterion); $\mathrm{SE}_{M_{\rho}}=$ standard error of $M_{\rho} ; 95 \%$ Conf. Int. $=95 \%$ Confidence Interval for $M_{\rho} ; \mathrm{SD}_{\rho}=$ standard deviation of estimated $\rho$ 's; $80 \%$ Cred. Int. $=80 \%$ Credibility Interval. 
Table 7

Results for Moderator Analyses for Task and Contextual Performance by Rater

\begin{tabular}{|c|c|c|c|c|c|c|c|c|c|c|c|c|c|}
\hline \multirow[b]{2}{*}{ Criterion } & \multirow[b]{2}{*}{ Rater Type } & \multirow[b]{2}{*}{$k$} & \multirow[b]{2}{*}{$\mathrm{N}$} & \multirow[b]{2}{*}{$M \mathrm{r}$} & \multirow[b]{2}{*}{$S D_{\mathrm{r}}$} & \multirow[b]{2}{*}{$M_{\rho}$} & \multirow{2}{*}{$\mathrm{SE}_{M p}$} & \multicolumn{2}{|c|}{$\begin{array}{c}95 \% \\
\text { Conf. Int. }\end{array}$} & \multicolumn{3}{|c|}{$\begin{array}{l}\text { 80\% Cred. } \\
\text { Int. }\end{array}$} & \multirow{2}{*}{$\begin{array}{c}\% \text { Due to } \\
\text { artifacts }\end{array}$} \\
\hline & & & & & & & & $\mathrm{L}$ & $\mathrm{U}$ & $\mathrm{SD}_{\rho}$ & $\mathrm{L}$ & $\mathrm{U}$ & \\
\hline \multicolumn{14}{|c|}{ Task Performance } \\
\hline & Self-rated & 10 & 3951 & .38 & .10 & .43 & .04 & .36 & .50 & .11 & .30 & .57 & 19.95 \\
\hline & Other-rated & 4 & 1,139 & .29 & .05 & .39 & .04 & .30 & .48 & .09 & .32 & .45 & 67.37 \\
\hline & Objective & 1 & 45 & .22 & - & - & - & - & - & - & - & - & - \\
\hline \multicolumn{14}{|c|}{ Contextual Performance } \\
\hline & Self-rated & 5 & 2495 & .25 & .08 & .30 & .04 & .22 & .38 & .09 & .19 & .40 & 24.96 \\
\hline & Other-rated & 5 & 1159 & .29 & .05 & .43 & .04 & .34 & .51 & .06 & .36 & .50 & 100.00 \\
\hline
\end{tabular}

Note. $k=$ the number of independent effect sizes included in each analysis; $\mathrm{N}=$ sample size. $M \mathrm{r}=$ mean uncorrected correlation; $S D \mathrm{r}=$ standard deviation of uncorrected correlations; $\mathrm{M}_{\rho}=$ mean corrected correlation (corrected for unreliability in the predictor and criterion); $\mathrm{SE}_{M_{\rho}}=$ standard error of $M_{\rho} ; 95 \%$ Conf. Int. $=95 \%$ Confidence Interval for $M_{\rho} ; \mathrm{SD}_{\rho}=$ standard deviation of estimated $\rho$ 's; $80 \%$ Cred. Int. $=80 \%$ Credibility Interval. 
Table 8

Results for Moderator Analyses for Publication Bias

\begin{tabular}{|c|c|c|c|c|c|c|c|c|c|c|c|c|c|}
\hline \multirow{2}{*}{$\frac{\text { Category }}{\text { Construct }}$} & \multirow[b]{2}{*}{ Publication Status } & \multirow[b]{2}{*}{$k$} & \multirow[b]{2}{*}{$\mathrm{N}$} & \multirow[b]{2}{*}{$M \mathrm{r}$} & \multirow[b]{2}{*}{$S D_{\mathrm{r}}$} & \multirow[b]{2}{*}{$M_{\rho}$} & \multicolumn{3}{|c|}{$\begin{array}{l}\text { 95\% Conf. } \\
\text { Int. }\end{array}$} & \multicolumn{3}{|c|}{$\begin{array}{l}80 \% \text { Cred. } \\
\text { Int. }\end{array}$} & \multirow{2}{*}{$\begin{array}{c}\% \text { Due to } \\
\text { artifacts }\end{array}$} \\
\hline & & & & & & & $\mathrm{SE}_{M \rho}$ & $\mathrm{L}$ & $\mathrm{U}$ & $\mathrm{SD}_{\rho}$ & $\mathrm{L}$ & $\mathrm{U}$ & \\
\hline \multicolumn{14}{|c|}{ Job Attitudes } \\
\hline \multicolumn{14}{|c|}{ Job Satisfaction } \\
\hline & Published & 13 & 6,715 & .43 & .19 & .49 & .05 & .39 & .60 & .19 & .25 & .74 & 3.64 \\
\hline & Unpublished & 7 & 3,010 & .54 & .15 & .60 & .06 & .49 & .71 & .15 & .41 & .79 & 5.27 \\
\hline \multicolumn{14}{|c|}{ Organizational Commitment } \\
\hline & Published & 12 & 6,981 & .47 & .10 & .59 & .03 & .53 & .65 & .11 & .46 & .72 & 10.91 \\
\hline & Unpublished & 2 & 588 & .46 & - & .55 & .03 & .49 & .60 & .04 & - & - & 100.00 \\
\hline \multicolumn{14}{|c|}{ Job Characteristics } \\
\hline \multicolumn{14}{|c|}{ Autonomy } \\
\hline & Published & 39 & 20,268 & .32 & .11 & .38 & .02 & .35 & .42 & .12 & .24 & .52 & 15.77 \\
\hline & Unpublished & 4 & 4,231 & .40 & .06 & .45 & .04 & .38 & .52 & .07 & .36 & .53 & 17.75 \\
\hline \multicolumn{14}{|c|}{ Feedback } \\
\hline & Published & 8 & 4,044 & .29 & .07 & .37 & .03 & .31 & .43 & .09 & .27 & .46 & 30.54 \\
\hline & Unpublished & 2 & 3,135 & .25 & .03 & .28 & .03 & .22 & .33 & .00 & .24 & .31 & 100.00 \\
\hline \multicolumn{14}{|c|}{ Social Support } \\
\hline & Published & 35 & 17,275 & .26 & .08 & .31 & .02 & .28 & .34 & .09 & .21 & .41 & 28.72 \\
\hline & Unpublished & 3 & 951 & .40 & .02 & .46 & .03 & .40 & .53 & .05 & .44 & .49 & 100.00 \\
\hline \multicolumn{14}{|c|}{ Dispositional Characteristics } \\
\hline \multicolumn{14}{|c|}{ Conscientiousness } \\
\hline & Published & 8 & 3,785 & .35 & .05 & .41 & .02 & .36 & .46 & .07 & .34 & .48 & 46.64 \\
\hline & Unpublished & 4 & 2,036 & .38 & .11 & .44 & .06 & .33 & .56 & .12 & .30 & .58 & 13.33 \\
\hline \multicolumn{14}{|c|}{ Positive Affect } \\
\hline & Published & 8 & 3,257 & .37 & .10 & .45 & .04 & .37 & .53 & .11 & .32 & .58 & 16.54 \\
\hline & Unpublished & 6 & 3,645 & .44 & .11 & .51 & .04 & .42 & .59 & .12 & .37 & .64 & 17.61 \\
\hline
\end{tabular}

Note. $k=$ the number of independent effect sizes included in each analysis; $\mathrm{N}=$ sample size. $\mathrm{Mr}=$ mean uncorrected correlation; $S D \mathrm{r}=$ standard deviation of uncorrected correlations; $\mathrm{M}_{\rho}=$ mean corrected correlation (corrected for unreliability in the predictor and criterion); $\mathrm{SE}_{M_{\rho}}=$ standard error of $M_{\rho} ; 95 \%$ Conf. Int. $=95 \%$ Confidence Interval for $M_{\rho} ; \mathrm{SD}_{\rho}=$ standard deviation of estimated $\rho$ 's; $80 \%$ Cred. Int. $=80 \%$ Credibility Interval. 
Table 9

Meta-analysis of Relationships Between Variables in Incremental Validity Analyses

\begin{tabular}{|c|c|c|c|c|c|c|c|c|c|c|}
\hline \multirow[t]{2}{*}{ Construct } & \multicolumn{2}{|c|}{ Engagement } & \multicolumn{2}{|c|}{ Job Satisfaction } & \multicolumn{2}{|c|}{$\begin{array}{l}\text { Organizational } \\
\text { Commitment }\end{array}$} & \multicolumn{2}{|c|}{ Job Involvement } & \multicolumn{2}{|c|}{ Task Performance } \\
\hline & $\begin{array}{c}M r, M_{\rho} \\
(95 \% \mathrm{CI})\end{array}$ & $\begin{array}{c}\mathrm{SD}_{\rho} \\
\left(\mathrm{SE}_{M \rho}\right)\end{array}$ & $\begin{array}{c}M \mathrm{r}, \boldsymbol{M}_{\boldsymbol{\rho}} \\
(95 \% \mathrm{CI})\end{array}$ & $\begin{array}{c}\mathrm{SD}_{\rho} \\
\left(\mathrm{SE}_{M \rho}\right)\end{array}$ & $\begin{array}{c}M \mathrm{r}, \boldsymbol{M}_{\boldsymbol{\rho}} \\
(95 \% \mathrm{CI})\end{array}$ & $\begin{array}{c}\mathrm{SD}_{\rho} \\
\left(\mathrm{SE}_{M \rho}\right)\end{array}$ & $\begin{array}{c}M r, M_{\rho} \\
(95 \% \mathrm{CI})\end{array}$ & $\begin{array}{c}\mathrm{SD}_{\rho} \\
\left(\mathrm{SE}_{M \rho}\right)\end{array}$ & $\begin{array}{c}M \mathrm{r}, \boldsymbol{M}_{\boldsymbol{\rho}} \\
(95 \% \mathrm{CI})\end{array}$ & $\begin{array}{c}\mathrm{SD}_{\rho} \\
\left(\mathrm{SE}_{M \rho}\right)\end{array}$ \\
\hline 1. Engagement & - & & & & & & & & & \\
\hline 2. Job Satisfaction & $\begin{array}{l}.46, .53 \\
(.44, .61)\end{array}$ & $\begin{array}{l}.19 \\
(.04)\end{array}$ & & & & & & & & \\
\hline$k, N$ & 20 & 9,725 & & & & & & & & \\
\hline $\begin{array}{l}\text { 3. Organizational } \\
\text { Commitment }\end{array}$ & $\begin{array}{c}.47, .59 \\
(.53, .64)\end{array}$ & $\begin{array}{l}.11 \\
(.03)\end{array}$ & $\begin{array}{c}.53, .64 \\
(.48, .80)\end{array}$ & $\begin{array}{l}.16 \\
(.08)\end{array}$ & - & & & & & \\
\hline$k, N$ & 14 & 7,569 & 4 & 2,834 & & & & & & \\
\hline 3. Job Involvement & $\begin{array}{c}.45, .52 \\
(.45, .59)\end{array}$ & $\begin{array}{l}.08 \\
(.04)\end{array}$ & $\begin{array}{c}.37, .45^{\mathrm{a}} \\
\left(^{\mathrm{g}}\right)\end{array}$ & $\begin{array}{l}.16 \\
\left({ }^{g}\right)\end{array}$ & $\begin{array}{c}.36, .44^{\mathrm{d}} \\
\left({ }^{\mathrm{g}}\right)\end{array}$ & $\begin{array}{l}.19 \\
\left({ }^{g}\right)\end{array}$ & & & & \\
\hline$k, N$ & 5 & 1,175 & 87 & 27,925 & 20 & 5,779 & & & & \\
\hline 5. Task Performance & $\begin{array}{c}.29, .39 \\
(.30, .48)\end{array}$ & $\begin{array}{l}.09 \\
(.04)\end{array}$ & $\begin{array}{c}18, . \mathbf{3 0}^{\mathbf{b}} \\
(.27, .33)\end{array}$ & $\begin{array}{l}.21 \\
(\mathrm{~g})\end{array}$ & $\begin{array}{c}\mathrm{g}, . \mathbf{1 8}^{\mathrm{e}} \\
(.01, .34)\end{array}$ & $\begin{array}{l}.10 \\
(\mathrm{~g})\end{array}$ & $\begin{array}{c}.07, .09^{\mathrm{a}} \\
(\mathrm{g})\end{array}$ & $\begin{array}{l}.08 \\
\left({ }^{g}\right)\end{array}$ & & \\
\hline$k, N$ & 4 & 1,139 & 312 & 54,471 & 87 & 20,973 & 8 & 2,313 & & \\
\hline $\begin{array}{l}\text { 6. Contextual } \\
\text { Performance }\end{array}$ & $\begin{array}{c}.29, .43 \\
(.34, .51)\end{array}$ & $\begin{array}{c}.06 \\
(.04)\end{array}$ & $\begin{array}{l}.20, .24^{\mathrm{c}} \\
(.22, .26)\end{array}$ & $\begin{array}{l}\mathrm{g} \\
\left({ }^{g}\right)\end{array}$ & $\begin{array}{l}.17, .20^{\mathrm{c}} \\
(.17, .24)\end{array}$ & $\left(\begin{array}{c}g \\
(\mathrm{~g})\end{array}\right.$ & $\underset{\left({ }^{\mathrm{g}}\right)}{.18, .25^{\mathrm{a}}}$ & $\begin{array}{l}.20 \\
(\mathrm{~g})\end{array}$ & $\mathrm{n} / \mathrm{a}^{\mathrm{h}}$ & $\mathrm{n} / \mathrm{a}$ \\
\hline$k, N$ & 5 & 1,159 & 72 & 7,100 & 54 & 5,133 & 7 & 3,478 & $\mathrm{n} / \mathrm{a}$ & $\mathrm{n} / \mathrm{a}$ \\
\hline
\end{tabular}

Note. Correlations with performance represent other-rated task and contextual performance. $k=$ the number of independent effect sizes included in each analysis; $N=$ sample size; $M \mathrm{r}=$ mean uncorrected correlation; $\mathrm{M}_{\rho}=$ mean corrected correlation (corrected for unreliability in the predictor and criterion); $95 \% \mathrm{CI}=95 \%$ Confidence Interval for $M_{\rho} ; \mathrm{SD}_{\rho}=$ standard deviation of estimated $\rho$ 's; $\mathrm{SE}_{M_{\rho}}=$ standard error of $M_{\rho}$. 
${ }^{a}$ Assumed values, calculated as corrected sample-weighted mean correlations derived from Brown (1996). ${ }^{\mathrm{b}}$ Judge et al. (2001). ${ }^{\mathrm{c}}$ LePine et al. (2002). ${ }^{\mathrm{d}}$ Mathieu \& Zajac (1990). ${ }^{\mathrm{e}}$ Riketta (2002). ${ }^{\mathrm{f}}$ Lee \& Ashforth (1996). ${ }^{\mathrm{g}}$ Information not provided in article. ${ }^{\mathrm{h}}$ The relationship between task performance and contextual performance was not calculated because each was involved in separate analysis. 
2

3

4

5

6

7

8

9

10

11

12

13

14

15

16

17

18

19

20

21

22

23

24

25

26

27

28

29

30

31

32

33

34

35

36

37

38

39

40

41

42

43

44

45

46

47

48

49

50

51

52

53

54

55

56

57

58

59

60

Table 10

Incremental Validity Analysis for Task and Contextual Performance

\begin{tabular}{lcc}
\hline \multirow{2}{*}{ Predictor } & \multicolumn{2}{c}{ Task Performance } \\
\hline Job Satisfaction & Step 1 & Step 2 \\
Organizational Commitment & $.33^{* * *}$ & $.24^{* * *}$ \\
Job Involvement & -.01 & $-.16^{* * *}$ \\
Engagement & $-.06^{* * *}$ & $-.18^{* * *}$ \\
\hline \multicolumn{1}{c}{ Total $\mathrm{R}^{2}$} & & $.43^{* * *}$ \\
$\Delta \mathrm{R}^{2}$ & $.11^{* * *}$ & $.30^{* * *}$ \\
\hline
\end{tabular}

Contextual Performance

\begin{tabular}{lcc} 
& Step 1 & Step 2 \\
\hline Job Satisfaction & $.14^{* * *}$ & $.06^{* * *}$ \\
Organizational Commitment & $.03^{*}$ & $-.12^{* * *}$ \\
Job Involvement & $.17^{* * *}$ & $.04^{* * *}$ \\
Engagement & & $.44^{* * *}$ \\
\hline \multicolumn{1}{c}{ Total $\mathrm{R}^{2}$} & $.05^{* * *}$ & $.21^{* * *}$ \\
\multicolumn{1}{c}{$\Delta \mathrm{R}^{2}$} & & $.16^{* * *}$ \\
\hline
\end{tabular}

Note. ${ }^{*} p<.05 . * * p<.01 . * * * p<.001 . \mathrm{N}_{\mathrm{h}}=3698$ for task performance and 3191 for contextual performance. Values are standardized estimates $(\beta \mathrm{s})$. 
Table 11

Meta-analysis of Relationships between Variables in Path Model

\begin{tabular}{|c|c|c|c|c|c|c|c|c|c|c|c|c|c|c|c|c|c|c|}
\hline 9 Construct & Engage & ment & Auton & & Task Va & riety & Task Sign & icance & Feedb & & $\begin{array}{r}\text { Transforn } \\
\text { Leader }\end{array}$ & thional & Positiv & Affect & Conscient & ousness & $\begin{array}{r}\mathrm{T} \\
\text { Perfo }\end{array}$ & $\begin{array}{l}\mathrm{k} \\
\text { ance }\end{array}$ \\
\hline 11 & $\begin{array}{c}M \mathrm{r}, \boldsymbol{M}_{\rho} \\
(95 \% \mathrm{CI}) \\
\end{array}$ & $\begin{array}{c}\mathrm{SD}_{\rho} \\
\left(\mathrm{SE}_{M_{\rho}}\right)\end{array}$ & $\begin{array}{c}M r, M_{\rho} \\
(95 \% \mathrm{CI}) \\
\end{array}$ & $\begin{array}{c}\mathrm{SD}_{\rho} \\
\left(\mathrm{SE}_{M \rho}\right) \\
\end{array}$ & $\begin{array}{c}M \mathrm{r}, \boldsymbol{M}_{\rho} \\
(95 \% \mathrm{CI}) \\
\end{array}$ & $\begin{array}{c}\mathrm{SD}_{\rho} \\
\left(\mathrm{SE}_{M \rho}\right)\end{array}$ & $\begin{array}{c}M \mathrm{r}, \boldsymbol{M}_{\rho} \\
(95 \% \mathrm{CI}) \\
\end{array}$ & $\begin{array}{c}\mathrm{SD}_{\rho} \\
\left(\mathrm{SE}_{M_{\rho}}\right) \\
\end{array}$ & $\begin{array}{c}M \mathrm{r}, \boldsymbol{M}_{\rho} \\
(95 \% \mathrm{CI}) \\
\end{array}$ & $\begin{array}{c}\mathrm{SD}_{\rho} \\
\left(\mathrm{SE}_{M_{\rho}}\right) \\
\end{array}$ & $\begin{array}{c}M \mathrm{r}, \boldsymbol{M}_{\rho} \\
(95 \% \mathrm{CI}) \\
\end{array}$ & $\begin{array}{c}\mathrm{SD}_{\rho} \\
\left(\mathrm{SE}_{M_{\rho}}\right)\end{array}$ & $\begin{array}{c}M \mathrm{Mr}, \boldsymbol{M}_{\rho} \\
(95 \% \mathrm{CI}) \\
\end{array}$ & $\begin{array}{c}\mathrm{SD}_{\rho} \\
\left(\mathrm{SE}_{M \rho}\right) \\
\end{array}$ & $\begin{array}{c}M \mathrm{r}, \boldsymbol{M}_{\rho} \\
(95 \% \mathrm{CI}) \\
\end{array}$ & $\begin{array}{c}\mathrm{SD}_{\rho} \\
\left(\mathrm{SE}_{M_{\rho}}\right) \\
\end{array}$ & $\begin{array}{c}M \mathrm{r}, \boldsymbol{M}_{\rho} \\
(95 \% \mathrm{CI}) \\
\end{array}$ & $\begin{array}{c}\mathrm{SD}_{\rho} \\
\left(\mathrm{SE}_{M \rho}\right)\end{array}$ \\
\hline $\begin{array}{l}12 . \text { Engagement } \\
13 \text {. Engeme } \\
14, N\end{array}$ & - & & & & & & & & & & & & & & & & & \\
\hline $\begin{array}{l}15 \\
16\end{array}$ & $\begin{array}{c}.33, .39 \\
(.36, .43)\end{array}$ & $\begin{array}{l}.11 \\
(.02)\end{array}$ & - & & & & & & & & & & & & & & & \\
\hline $17, N$ & 43 & 24499 & & & & & & & & & & & & & & & & \\
\hline $\begin{array}{l}\text { 18. Task Variety } \\
19\end{array}$ & $\begin{array}{c}.44, .53 \\
(.49, .57)\end{array}$ & $\begin{array}{l}.06 \\
(.02)\end{array}$ & $\begin{array}{c}.38, .47 \\
(.35, .60)\end{array}$ & $\begin{array}{l}.15 \\
(.06)\end{array}$ & - & & & & & & & & & & & & & \\
\hline $20, N$ & 9 & 9211 & 6 & 2124 & & & & & & & & & & & & & & \\
\hline $\begin{array}{l}21 . \text { Task Significance } \\
22\end{array}$ & $\begin{array}{c}.42, .51 \\
(.44, .57)\end{array}$ & $\begin{array}{l}.06 \\
(.03)\end{array}$ & $\begin{array}{l}.33, .44^{\mathrm{a}} \\
(.35, .53)\end{array}$ & $\begin{array}{l}.08 \\
(.04)\end{array}$ & $\begin{array}{l}.38, .51^{\mathbf{a}} \\
(.39, .64)\end{array}$ & $\begin{array}{l}.11 \\
(.06)\end{array}$ & - & & & & & & & & & & & \\
\hline $23, N$ & 4 & 5870 & 3 & 875 & 3 & 1061 & & & & & & & & & & & & \\
\hline 24.5. Feedback & $\begin{array}{c}.27, .33 \\
(.28, .38)\end{array}$ & $\begin{array}{l}.08 \\
(.02)\end{array}$ & $\begin{array}{c}.27, .34 \\
(.26, .42)\end{array}$ & $\begin{array}{l}.11 \\
(.04)\end{array}$ & $\begin{array}{l}.35, .46 \\
(.26, .65)\end{array}$ & $\begin{array}{l}.20 \\
(.10)\end{array}$ & $\begin{array}{l}.33, . \mathbf{4 3}^{\mathrm{a}} \\
(.32, .54)\end{array}$ & $\begin{array}{l}.09 \\
(.05)\end{array}$ & - & & & & & & & & & \\
\hline $\begin{array}{l}26, N \\
27\end{array}$ & 10 & 7179 & 7 & 3009 & 4 & 1700 & 3 & 1061 & & & & & & & & & & \\
\hline $\begin{array}{l}\text { 28. Transformational } \\
2 \text { Geadership }\end{array}$ & $\begin{array}{c}.24, .27 \\
(.18, .36)\end{array}$ & $\begin{array}{l}.06 \\
(.05)\end{array}$ & $\begin{array}{l}.31, .37^{\mathbf{b}} \\
(.28, .47)\end{array}$ & $\begin{array}{l}.02 \\
(.05)\end{array}$ & $\begin{array}{l}.31, .37^{\mathbf{b}} \\
(.28, .47)\end{array}$ & $\begin{array}{l}.02 \\
(.05)\end{array}$ & $\begin{array}{l}.25, .29^{\mathbf{i}} \\
(.24, .35)\end{array}$ & $\begin{array}{l}.06 \\
(.03)\end{array}$ & $\begin{array}{l}.31, .37^{\mathbf{i}} \\
(.31, .42)\end{array}$ & $\begin{array}{l}.10 \\
(.03)\end{array}$ & - & & & & & & & \\
\hline $30, N$ & 4 & 777 & 3 & 868 & 3 & 868 & 4 & 2407 & 4 & 2407 & & & & & & & & \\
\hline $\begin{array}{l}\text { 31. Positive Affect } \\
32\end{array}$ & $\begin{array}{c}.37, . \mathbf{4 3} \\
(.35, .52)\end{array}$ & $\begin{array}{l}.16 \\
(.04)\end{array}$ & $\begin{array}{l}.09, .13^{\mathbf{c}} \\
(-.03, .28)\end{array}$ & $\begin{array}{l}.08 \\
(.08)\end{array}$ & $\begin{array}{l}.08, .1 \mathbf{f o}^{\mathbf{f}} \\
(-.01, .20)\end{array}$ & $\begin{array}{l}.09 \\
(.06)\end{array}$ & $\begin{array}{l}.13, .16^{\mathbf{j}} \\
(.08, .25)\end{array}$ & $\begin{array}{l}.06 \\
(.04)\end{array}$ & $\begin{array}{l}.12, .14^{\mathbf{k}} \\
(.08, .21)\end{array}$ & $\begin{array}{l}.08 \\
(.03)\end{array}$ & $\begin{array}{l}.09, .06^{\mathbf{m}} \\
(-.06, .18)\end{array}$ & $\begin{array}{l}.11 \\
(.06)\end{array}$ & - & & & & & \\
\hline $33, N$ & 14 & 6715 & 3 & 470 & 3 & 511 & 2 & 847 & 5 & 1341 & 3 & 1192 & & & & & & \\
\hline $\begin{array}{l}\text { 34. } \\
\text { 35. onscientiousness }\end{array}$ & $\begin{array}{c}.36, .42 \\
(.37, .47)\end{array}$ & $\begin{array}{l}.09 \\
(.03)\end{array}$ & $\begin{array}{l}.12, .16 \\
(.02, .31)\end{array}$ & $\begin{array}{l}.04 \\
(.07)\end{array}$ & $\begin{array}{l}.13, .16^{\mathbf{g}} \\
(.04, .28)\end{array}$ & $\begin{array}{l}.09 \\
(.06)\end{array}$ & $\begin{array}{l}.12, .15^{\mathbf{k}} \\
(.07, .24)\end{array}$ & $\begin{array}{l}.07 \\
(.04)\end{array}$ & $\begin{array}{c}.12, .14^{\mathbf{l}} \\
(-.10, .38)\end{array}$ & $\begin{array}{l}.04 \\
(.12)\end{array}$ & $\begin{array}{l}.07, . \mathbf{0 3}{ }^{\mathbf{n}} \\
(-.07, .13)\end{array}$ & $\begin{array}{l}.07 \\
(.05)\end{array}$ & $\begin{array}{l}{ }^{t}, .00{ }^{q} \\
\left({ }^{t},{ }^{t}\right)\end{array}$ & ${ }^{\mathrm{t}}$ & - & & & \\
\hline $\begin{array}{l}36, N \\
37\end{array}$ & 12 & 5821 & 3 & 624 & 2 & 348 & 7 & 1151 & 2 & 179 & 3 & 1148 & 632 & 683001 & & & & \\
\hline $\begin{array}{l}\text { 38. Task } \\
\text { 39 Performance }\end{array}$ & $\begin{array}{c}.29, .39 \\
(.30, .48)\end{array}$ & $\begin{array}{c}.09 \\
(.04)\end{array}$ & $\begin{array}{l}.18, .23^{\mathbf{d}} \\
(.19, .28)\end{array}$ & $\left(^{t}\right)$ & $\begin{array}{l}.21, .23^{\mathbf{d}} \\
(.16, .29)\end{array}$ & $\left(^{\mathrm{t}}\right.$ & $\begin{array}{l}.16, .23{ }^{\mathbf{d}} \\
(.16, .29)\end{array}$ & $\left(^{t}\right)$ & $\begin{array}{l}.14, .20{ }^{\mathbf{d}} \\
(.15, .24)\end{array}$ & $\left(^{t}\right)$ & $\begin{array}{l}.18, .20{ }^{\circ} \\
(.14, .26)\end{array}$ & $\begin{array}{l}.06 \\
(.03)\end{array}$ & $\begin{array}{c}.04, .07^{r} \\
\left({ }^{\mathrm{t}},{ }^{\mathrm{t}}\right)\end{array}$ & $\begin{array}{l}.14 \\
\left({ }^{t}\right)\end{array}$ & $\begin{array}{c}.17, .28^{r} \\
\left({ }^{t},{ }^{t}\right)\end{array}$ & $\begin{array}{l}.16 \\
\left({ }^{t}\right)\end{array}$ & & \\
\hline $4 \circledast, N$ & 4 & 1139 & 42 & 7886 & 2 & 918 & 20 & 3503 & 26 & 5241 & 4 & 1893 & 75 & 11940 & 90 & 19460 & & \\
\hline $\begin{array}{l}41 \\
42 \text {. Contextual } \\
43 \text { Performance }\end{array}$ & $\begin{array}{c}.29, .43 \\
(.34, .51)\end{array}$ & $\begin{array}{c}.06 \\
(.04)\end{array}$ & $\begin{array}{l}.28, .35^{\mathrm{e}} \\
(.18, .52)\end{array}$ & $\begin{array}{l}.15 \\
(.09)\end{array}$ & $\begin{array}{l}\mathrm{t}, \\
\left(\mathrm{t}, .2{ }^{\mathrm{t}}\right. \\
\mathrm{h}\end{array}$ & ${ }^{\mathrm{t}}$ & $\begin{array}{l}{ }^{t}, .20 \\
\left({ }^{t},{ }^{t}\right.\end{array}$ & ${ }^{\mathrm{t}}$ & $\begin{array}{l}\mathrm{t},, .18^{\mathrm{h}} \\
\left(\mathrm{t},{ }^{\mathrm{t}}\right)\end{array}$ & $\left(^{t}\right)$ & $\begin{array}{c}.25, .29^{p} \\
\left({ }^{\mathrm{t}},{ }^{\mathrm{t}}\right)\end{array}$ & $\begin{array}{c}\mathrm{t} \\
(.02)\end{array}$ & $\begin{array}{c}.18, .23 \\
\left(\mathrm{t},{ }^{\mathrm{t}}\right)\end{array}$ & $\left(^{t}\right)$ & $\begin{array}{c}.24, .30^{s} \\
\left({ }^{t},{ }^{t}\right)\end{array}$ & $\left.{ }^{t}{ }^{t}\right)$ & $\mathrm{n} / \mathrm{a}^{1}$ & $\mathrm{n} / \mathrm{a}$ \\
\hline $44, N$ & 5 & 1159 & 3 & 479 & 8 & 1948 & 8 & 1948 & 7 & 1909 & 6 & 2562 & 5 & 970 & 12 & 1963 & $\mathrm{n} / \mathrm{a}$ & $\mathrm{n} / \mathrm{a}$ \\
\hline
\end{tabular}


Note. Correlations with performance represent other-rated task and contextual performance when possible. $k=$ the number of independent effect sizes included in each analysis; $N=$ sample size; $M \mathrm{r}=$ mean uncorrected correlation; $\mathrm{M}_{\rho}=$ mean corrected correlation (corrected for unreliability in the predictor and criterion); $95 \%$ $\mathrm{CI}=95 \%$ Confidence Interval for $M_{\rho} ; \mathrm{SD}_{\rho}=$ standard deviation of estimated $\rho$ 's; $\mathrm{SE}_{M_{\rho}}=$ standard error of $M_{\rho}$.

${ }^{a}$ Assumed values, calculated as corrected sample-weighted mean correlations derived from Spector \& Jex (1991), Munz, Huelsman, Konold, \& McKinney (1996), and Thomas et al. (2004). ${ }^{\mathrm{b}}$ Assumed values, calculated as corrected sample-weighted mean correlations derived from Purvanova, Bono, \& Dzieweczynski (2006), Whittington, Goodwin, \& Murray (2004), and Judge \& Piccolo (2004). ${ }^{\mathrm{c}}$ Assumed values, calculated as corrected sample-weighted mean correlations derived from Barrick \& Mount (1993), van den Berg \& Feij (2003), and Thomas et al. (2004). ${ }^{\mathrm{d}}$ Humphrey et al. (2007). ${ }^{\mathrm{e}}$ Assumed values, calculated as corrected sample-weighted mean correlations derived from Bakker, Demerouti, \& Verbeke (2004), Fuller, Marler, \& Hester (2006), and Parker, Williams, \& Turner (2006). ${ }^{\mathrm{f}}$ Assumed values, calculated as corrected sample-weighted mean correlations derived from Kim et al. (2009), van den Berg \& Feij (2003), and Thomas et al. (2004). ${ }^{\mathrm{g}}$ Assumed values, calculated as corrected sample-weighted mean correlations derived from Kim et al. (2009) and van den Berg \& Feij (2003). ${ }^{\mathrm{h}}$ Assumed values, calculated as corrected sample-weighted mean correlations derived from Podsakoff, MacKenzie, Paine, \& Bachrach (2000). ${ }^{\mathrm{i}}$ Assumed values, calculated as corrected sample-weighted mean correlations derived from Purvanova et al. (2006), Whittington et al. (2004), Judge \& Piccolo (2004), and Podsakoff, MacKenzie, \& Bommer (1996). ${ }^{j}$ Assumed values, calculated as corrected sample-weighted mean correlations derived from Rothbard (2001) and Thomas et al. (2004). ${ }^{\mathrm{k}}$ Averaged other JC studies. ${ }^{1}$ Assumed values, calculated as corrected sample-weighted mean correlations derived from Simmering, Colquitt, Noe, \& Porter (2003) and Demerouti (2006). ${ }^{\mathrm{m}}$ Assumed values, calculated as corrected sample-weighted mean correlations derived from Campbell, Ward, Sonnenfeld, \& Agle (2008), Felfe \& Schyns (2006), and Saltz (2004). ${ }^{\mathrm{n}}$ Assumed values, calculated as corrected sample-weighted mean correlations derived from Campbell et al. (2008), Connell (2005), and Saltz (2004). ${ }^{\circ}$ Assumed values, calculated as corrected sample-weighted mean correlations derived from Piccolo \& Colquitt (2006), Howell \& Hall-Merenda (1999), Whittington et al. (2004), and Podsakoff et al. (1996). ${ }^{\mathrm{p}}$ Organ \& Ryan (1995). ${ }^{\mathrm{q}}$ Ones, Viswesvaran, \& Reiss (1996). ${ }^{\mathrm{r}}$ Salgado (2003). ${ }^{\mathrm{s}}$ Borman, Penner, Allen, \& Motowidlo (2001). ${ }^{\mathrm{t}}$ Information not provided in article. 